\title{
A Comparison of Hydrocarbon-Related Landscape Disturbance Patterns Along the New York-Pennsylvania Border, 2004-2013
}

Scientific Investigations Report 2019-5096 



\section{A Comparison of Hydrocarbon-Related Landscape Disturbance Patterns Along the New York-Pennsylvania Border, 2004-2013}

By Coral M. Roig-Silva, Lesley E. Milheim, E. Terrence Slonecker, Siddiq Kalaly, and Joseph Chestnut

Scientific Investigations Report 2019-5096 


\title{
U.S. Department of the Interior \\ DAVID BERNHARDT, Secretary
}

\author{
U.S. Geological Survey \\ James F. Reilly, Director
}

U.S. Geological Survey, Reston, Virginia: 2019

For more information on the USGS — the Federal source for science about the Earth, its natural and living resources, natural hazards, and the environment—visit https://www.usgs.gov or call 1-888-ASK-USGS.

For an overview of USGS information products, including maps, imagery, and publications, visit https://store.usgs.gov/.

Any use of trade, firm, or product names is for descriptive purposes only and does not imply endorsement by the U.S. Government.

Although this information product, for the most part, is in the public domain, it also may contain copyrighted materials as noted in the text. Permission to reproduce copyrighted items must be secured from the copyright owner.

Suggested citation:

Roig-Silva, C.M., Milheim, L.E., Slonecker, E.T., Kalaly, S., and Chestnut, J., 2019, A comparison of hydrocarbonrelated landscape disturbance patterns along the New York-Pennsylvania border, 2004-2013: U.S. Geological Survey Scientific Investigations Report 2019-5096, 23 p., https://doi.org/10.3133/sir20195096.

Associated data for this publication:

Roig-Silva, C.M., Milheim, L.E., and Slonecker, E.T., 2019, Natural gas and oil drilling disturbance in the Marcellus Shale region of the New York-Pennsylvania border: U.S. Geological Survey data release, https://doi.org/10.5066/ F7TT4067.

ISSN 2328-0328 (online) 


\section{Contents}

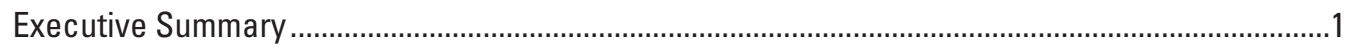

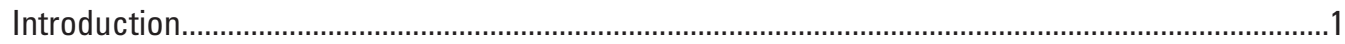

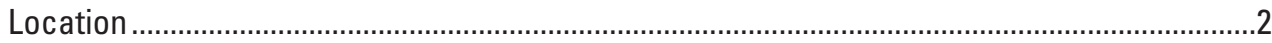

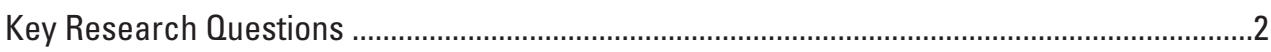

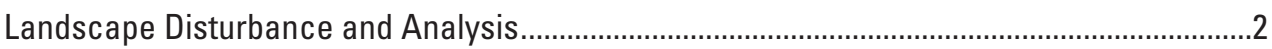

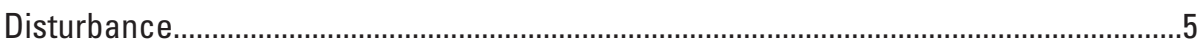

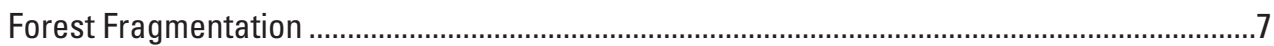

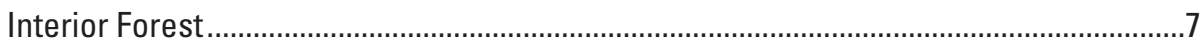

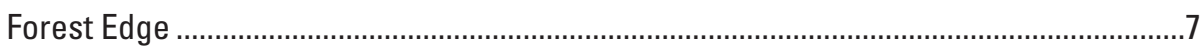

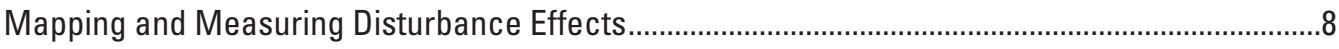

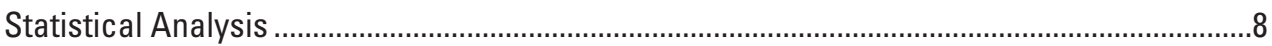

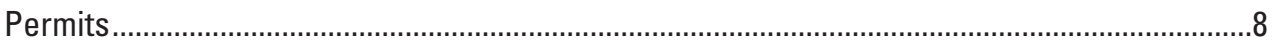

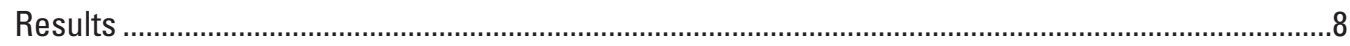

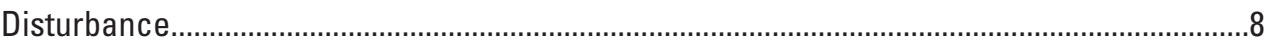

Land-Use and Land-Cover Change ................................................................................12

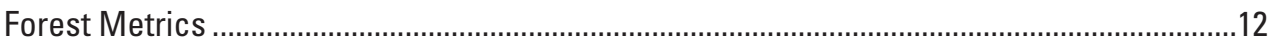

Relationship of Oil and Gas Development to Land-Use and Land-Cover Change ..................12

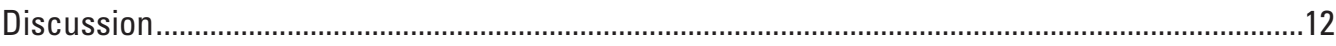

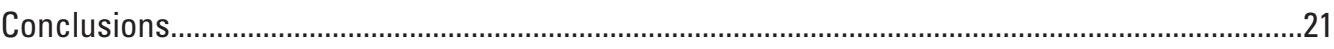

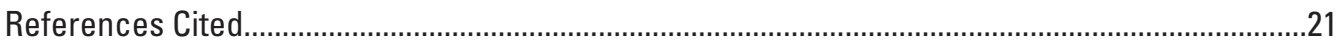

\section{Figures}

1. Map of the Appalachian Basin province showing the Marcellus Shale Assessment Units and the 10 New York and Pennsylvania counties studied in this report.

2. Bar graphs showing the percentage of the three land-cover classes-forest, agricultural land, and developed land - that make up each of the counties in the five-county New York and Pennsylvania regions of the study....................................

3. Example of hydrocarbon extraction disturbance footprint with respect to its surrounding landscape.

4. A map of the New York-Pennsylvania 10-county study area, in relation to the Interior Marcellus Assessment Unit, showing the locations and proximities of developed and undeveloped oil- and gas-drilling permits

5. A bar graph comparing oil- and gas-drilling permits to developed sites for the hydrocarbon types discussed in this study-shale gas, non-shale gas, oil, and other-for the New York and Pennsylvania five-county regions.

6. Bar graphs showing mean oil- and gas-development disturbance, in hectares per site. Disturbance is shown by type of site for each of the counties in the five-county New York and Pennsylvania regions and each State's five-county study region

7. Bar graph showing percentages of forest and agricultural land lost compared with percentages of oil and gas development in New York and Pennsylvania counties 
8. Bar graph showing percentages of land-use and land-cover change, by county and five-county region, for agricultural land, forest, and oil and gas development in New York and Pennsylvania

9. Bar graph showing percentages of forest change caused by oil- and gas-development disturbance in the five-county New York and Pennsylvania regions

10. Bar graph showing the percentage of forest change by type (percent forest, percent interior forest, percent forest edge) for each county and each five-county region in the study, grouped by State

11. Map showing the contrast between oil- and gas-development-site density for locations in McKean and Bradford Counties, Pennsylvania

12. Map showing the percentage of combined agricultural land and forest loss by county

\section{Tables}

1. Disturbance summary statistics for New York and Pennsylvania counties. "Hectares per site" is the mean area for sites only, whereas "Disturbed hectares per site" accounts for the area used for roads and pipelines in the mean .....10

2. Complete land-use and land-cover change details from oil and gas development for the New York five-county region of the study and the Pennsylvania five-county region of the study.....

3. Forest area metrics for the New York and Pennsylvania five-county regions

4. Summary of the Pearson correlation coefficient for changes in metrics-for the entire 10-county region, the New York counties in the study, and the Pennsylvania counties in the study — shown as statistical significance levels

5. Summary of regional land-use and land-cover change for each New York and Pennsylvania five-county region, and for the entire 10-county region, from oil and gas development

\section{Conversion Factors}

International System of Units to U.S. customary units

\begin{tabular}{|c|c|c|}
\hline Multiply & By & To obtain \\
\hline \multicolumn{3}{|c|}{ Length } \\
\hline meter (m) & 3.281 & foot $(\mathrm{ft})$ \\
\hline kilometer (km) & 0.6214 & mile (mi) \\
\hline meter $(\mathrm{m})$ & 1.094 & yard (yd) \\
\hline \multicolumn{3}{|c|}{ Area } \\
\hline square meter $\left(\mathrm{m}^{2}\right)$ & 0.0002471 & acre \\
\hline hectare (ha) & 2.471 & acre \\
\hline
\end{tabular}

\section{Datum}

Horizontal coordinate information is referenced to the North American Datum of 1983 (NAD 83). 


\section{Abbreviations}

ATtILA Analytical Tools Interface for Landscape Assessments

EPA U.S. Environmental Protection Agency

GIS geographic information system

ha hectares

LULC land use and land cover

m meter

UOG unconventional oil and gas

USGS U.S. Geological Survey 



\title{
A Comparison of Hydrocarbon-Related Landscape Disturbance Patterns Along the New York-Pennsylvania Border, 2004-2013
}

\author{
By Coral M. Roig-Silva, Lesley E. Milheim, E. Terrence Slonecker, Siddiq Kalaly, and Joseph Chestnut
}

\section{Executive Summary}

The New York-Pennsylvania area has a long history of hydrocarbon extraction, and the addition of shale gas extraction methods contributes to landscape disturbance borne by previously developed oil and non-shale gas resources. The main unconventional extraction method used to extract shale gas from the Marcellus Shale located in New York and Pennsylvania is hydraulic fracturing, or "fracking," although other conventional methods are used extensively. All forms of hydrocarbon extraction disturb the surrounding landscape to some extent, primarily in the form of land clearance and degradation, road construction, and pipeline development, although the effects of these disturbances are not fully understood.

In this study, landscape-change metrics and indicators are used to analyze change in a 10-county region along the New York-Pennsylvania border-the New York counties of Allegany, Steuben, Chemung, Tioga, and Broome, and the Pennsylvania counties of McKean, Potter, Tioga, Bradford, and Susquehanna. This 10-county region was selected due to the differences in policies between the States of New York and Pennsylvania. While fracking occurred extensively in Pennsylvania over the past 10 years or more, the State of New York issued a temporary moratorium against hydraulic fracturing in 2010 - citing repercussions that might affect air quality, water quality, and public health - and officially banned hydraulic fracturing in June 2015.

The quantification of landscape disturbance due to hydrocarbon extraction activities is presented in this report as land-use and land-cover (LULC) change between 2004 and 2013 and defined using specific disturbance categories (including well sites, roads, and pipelines) to compare the disturbances and changes, by county, on both sides of the New York-Pennsylvania border. The quantification was accomplished by gathering the signatures of disturbance from high-resolution aerial images, comparing the derived totals of disturbance, and then computing landscape metrics in a geographic information system (GIS) environment.

The collected data represent a summation of landscape disturbance from oil and gas development, as some of the data represented were established decades earlier. The Analytical Tools Interface for Landscape Assessments (ATtILA) software was used to calculate land-cover area and landscape metrics for each shale gas, non-shale gas, oil, and other infrastructure types associated with hydrocarbons across each county and both five-county regions in the study area. The three primary metrics used to describe changes in forest structure were (1) forest area, (2) interior forest area, and (3) forest edge area. The changes in metrics were subsequently evaluated using the Pearson correlation coefficient.

Overall, the disturbed-area footprint in the Pennsylvania region is considerably larger than the disturbed-area footprint in the New York region (13,687.9 hectares [ha] in Pennsylvania; $3,840.5$ ha in New York). Disturbance per site is similar, with 1.2 disturbed ha per site in New York and 1.6 disturbed ha per site in Pennsylvania.

In the New York-Pennsylvania 10-county region, hydrocarbon-development and extraction disturbance strongly correlate with a reduction in the percentage of forest for the entire region. This observation also appears to be true in the New York five-county region for forest area. This form of disturbance in the New York five-county region shows significantly correlated changes in forest metrics $(-0.4$ percent total forest area), particularly in the percentage of interior forest $(-1.2$ percent total area) and forest edge $(+0.7$ percent total area). On the other hand, gas and hydrocarbon-development and extraction disturbance (1.0 percent total area) in the Pennsylvania five-county region strongly correlates with a total decline in forest area and agricultural land area ( -0.8 percent combined total area) but not with either landcover class separately.

\section{Introduction}

The need for cleaner-burning energy, coupled with technological advances in accessing deep, hydrocarbon-rich geologic formations, has led to intense efforts to find and extract natural gas and other hydrocarbons from deep, underground geologic formations across the Nation. One of these formations, the Marcellus Shale, is the target of extensive drilling and production in the Allegheny Basin province, which extends from New York to West Virginia (fig. 1). The Marcellus Shale is located between 600 and 3,000 meters (m) below land surface (Coleman and others, 2011). 
Horizontal drilling and hydraulic fracturing processes garnered worldwide attention through the large amounts of fresh water (116 billion liters per year for shale gas; Kondash and Vengosh, 2015) and proprietary fluids used in the hydraulic fracturing process, both of which caused numerous environmental concerns, debates, and litigation. However, an often-overlooked issue in the hydrocarbon-extraction dialogue is the indirect effect these practices have on the Nation's landscape.

A standard unconventional oil and gas (UOG) well is drilled in a cleared and graded 2.5-ha area that can extend beyond the well pad (Slonecker and Milheim, 2015). The well-development process can include an infrastructure with many components, including small sedimentation ponds; large, lined wastewater impoundments; storage tanks; staging areas; temporary trailers; drill rigs; temporary and permanent road access; and pipelines that connect to oil- and gas-transportation infrastructure. Pipelines usually extend long distances across counties, but they can also go to processing facilities (Slonecker and Milheim, 2015) or across short distances to specially developed railway stations.

In both New York and Pennsylvania, UOG development is only part of the overall oil- and gas-extraction effort. Oil and gas wells were first developed in this region in the late 1800 s, and their development continues (Dresel and Rose, 2010). Oil and gas wells are drilled vertically and at shallower depths than UOG wells, and they also have a much smaller clearance footprint (Slonecker and Milheim, 2015), which allows their grouping in clusters or grids to extract resources more efficiently. Oil- and gas-well infrastructure typically includes sedimentation ponds, storage tanks, and access roads. Wells in depleted coal beds can use a low-volume version of hydraulic fracturing to free coalbed methane. Both well types and infrastructure systems are often developed proximate to one another, and their combined landscape disturbance can be substantial.

The accumulation of these kinds of landscape-clearance activities and other human interactions are often dramatic and can lead to consequences for ecosystems, wildlife, and human populations proximate to oil- and gas-extraction activities. Landscape disturbance can alter ecosystems and the services they provide by changing the spatial arrangement and connectivity of natural resources such as forests, water bodies, and wetlands. Landscape-disturbance data and analysis related to hydrocarbon extraction are presented in this report.

While hydraulic fracturing occurred extensively in Pennsylvania over the past 10 years or more, the State of New York created a temporary moratorium against hydraulic fracturing in 2010 (New York State Department of Environmental Conservation, 2015a, b), citing repercussions that might affect air quality, water quality, and public health. In June 2015, the State of New York officially banned hydraulic fracturing following the final release of a study by the New York State Department of Environmental Conservation, although litigation is expected to ensue (New York State Department of Environmental Conservation, 2015a, b). Regardless, in both New York and Pennsylvania, shallower oil- and gas-well drilling is ongoing.

\section{Location}

The assessment of landscape change in this report focuses on 10 counties: Bradford, McKean, Potter, Susquehanna, and Tioga Counties in Pennsylvania, and Allegany, Broome, Chemung, Steuben, and Tioga Counties in New York (fig. 1). All 10 counties lie within the Marcellus Shale development area known as the Marcellus Shale Play or the Interior Marcellus Assessment Unit. These counties were chosen for their position relative to the border between the two States and a "sweet spot" of highly productive Marcellus Shale (Stevens and Kuuskraa, 2009). Marcellus Shale in the area is exceptionally thick, ranging from about 61 to $122 \mathrm{~m}$ (Stevens and Kuuskraa, 2009). The region is rural, dominated by forest, and includes a substantial amount of agriculture (fig. 2).

\section{Key Research Questions}

A central goal of this report is the quantification of landscape disturbance as land-use and land-cover (LULC) change. The quantification of landscape disturbance is evaluated - by specific disturbance categories (including well sites, roads, and pipelines) and the comparison of disturbances and changes by county - on both sides of the States' border. The quantification was accomplished by way of collected disturbance signatures from high-resolution aerial images, comparing the derived totals of disturbance, and computing the landscape metrics in a geographic information system (GIS) environment. This report's research and monitoring focused on answering the following questions:

- What is the level of overall disturbance attributed to hydrocarbon-development activities in both New York and Pennsylvania, and how has this changed the landscape?

- What are the structural components (land-cover classes) of this change and how much change can be attributed to each class in both New York and Pennsylvania?

- How has the disturbance associated with natural gas exploration and development affected the structure, pattern, and process of critical ecosystems, especially forests, in both New York and Pennsylvania?

\section{Landscape Disturbance and Analysis}

Important, sometimes overlooked aspects of contemporary oil- and gas-development activities are the geographic locations, distributions, and spatial arrangements of these 


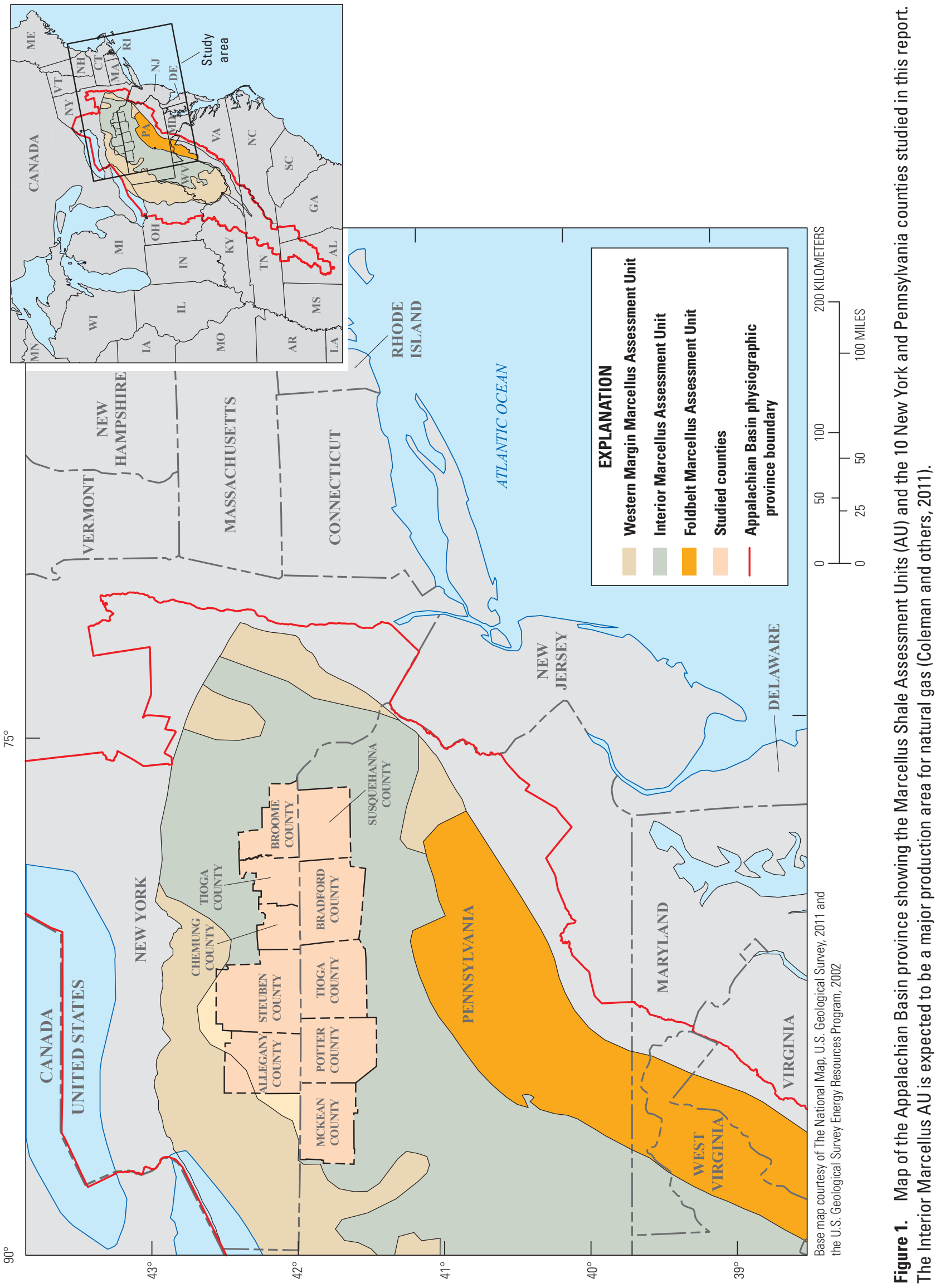




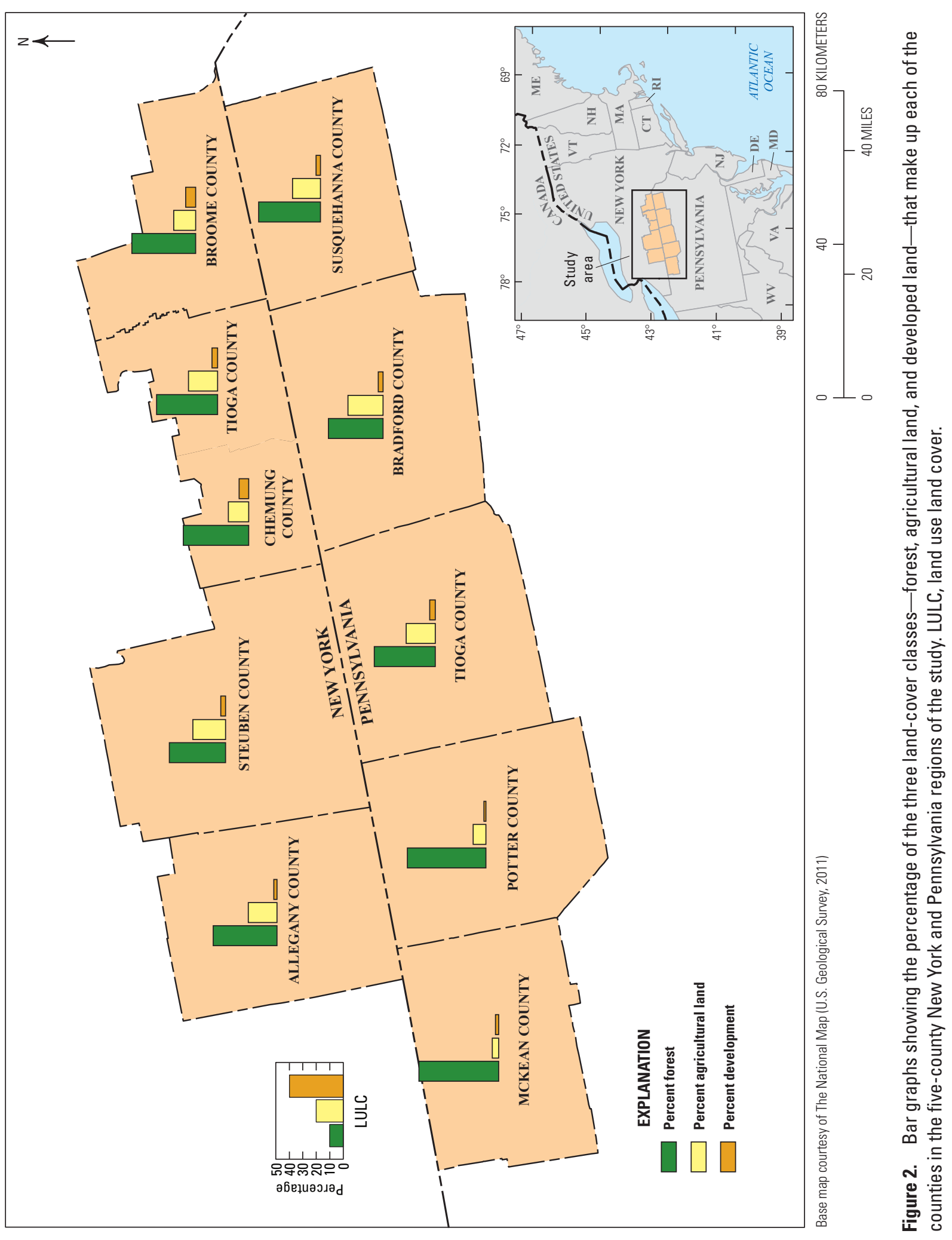


activities on the land surface. Energy extraction requires specific LULC change activities that alter critical aspects of the spatial pattern, form, and function of the natural landscape that in turn affect the ability of the resident ecosystems to provide essential ecological goods and services. These essential services affect the social, economic, and public health benefits the ecosystems provide. A critical challenge for geographic science is learning to understand and calibrate the effects of LULC change and the complex interaction between human and biotic systems at different natural, geographic, and political scales (Slonecker and others, 2012).

Understanding the dynamics of LULC change requires an awareness of the complex nature of human environmental systems and the development of a suite of tools that enables scientific investigations into the intricacies of LULC change. Tools of this type include traditional geographic data and analysis methods, such as remote sensing and GIS, alongside other innovative approaches used for understanding the dynamics of complex natural systems (O'Neill and others, 1997; Turner, 2005; Wickham and others, 2007). The landscape assessment method of O'Neill and others (1997) is one such approach. The concept of landscape assessment is derived from landscape ecology and is rooted in the realization that pattern and structure are essential components of ecological processes.

Landscape assessment uses spatially explicit imagery and GIS data on land cover, elevation, roads, hydrology, and vegetation, along with in-place sampling results, to compute a suite of numerical indicators, known as landscape metrics, to assess ecosystem conditions. The analysis of landscape metrics can reveal relationships between pattern and process (flow of energy) and other broad-scale ecological concerns such as habitat, conservation, and sustainability. Landscape analysis can be applied to biological and anthropogenic landscapes to explore LULC change and its effect on ecosystems and biological endpoints.

Landscape metrics are spatial and mathematical functions that enable objective descriptions of different landscape structure and pattern aspects (McGarigal and others, 2002). These metrics characterize the structures and environmental processes at the landscape and ecosystem levels. Metrics, such as average patch size, fragmentation, and interior forest dimension, capture the spatial characteristics of habitat quality and their potential effects on critical populations of animals and vegetation. Many landscape metrics are computed and used for specific purposes, but several researchers (Riitters and others, 1995; Wickham and Riitters, 1995; Wickham and others, 1997) have shown that metrics are often highly correlated, sensitive to misclassification and pixel size, and, to some extent, questionable regarding additional information value; in other words, some metrics overlap in the types of information they provide.

The landscape analysis presented in this report is based on the framework outlined in O'Neill and others (1997). The key landscape concepts and metrics reported here include changes in land-use and land-cover percentages and forest metrics with a primary focus on total disturbance, forest loss, interior forest loss, and forest edge increases. The formulae used to compute the metrics in this report are available in the software documentation for the Analytical Tools Interface for Landscape Assessments (ATtILA) software (Ebert and Wade, 2004). Computation details for determining the percentages of interior forest and the percentages of forest edge are documented by Riitters and others (2000). ATtILA is an extension developed by the U.S. Environmental Protection Agency (EPA) - designed for use with Esri's ArcView or ArcGIS software and available at https://www.epa.gov/ enviroatlas/attila-toolbox - to compute landscape, riparian, and watershed metrics at the county level, as explained in the ATtILA User Manual (Ebert and Wade, 2004), which can be obtained at https://www.epa.gov/eco-research/ analytical-tools-interface-landscape-assessments-user-manual.

\section{Disturbance}

The initial step in landscape analysis is to determine the spatial distribution of disturbance and identify hotspots of activity. Disturbance, in this report, is approached as a discrete value that is presented in graphic files and tables of summary statistics, which afford a greater focus on specific locations. An example of the distribution of natural gas extraction in Steuben County, N.Y., is found in figure 3, which shows how instances of disturbance are situated with respect to local land cover.

Disturbance is a crucial concept in a landscape-analysis approach and for ecology in general. Disturbances are discrete events in space and time that disrupt ecosystem structures and functions; they also change the physical environment and the availability of resources (White and Pickett, 1985; Turner and others, 2001). When a natural or anthropogenic disturbance occurs in natural systems, it generally changes abiotic and biotic conditions to favor the success of different species over those organisms present pre-disturbance. Oil and gas development lead to spatially explicit patterns of landscape disturbance, primarily from the construction of the associated infrastructure (fig. 3).

Landscape disturbance from oil and gas development includes land clearance and increased traffic and noise from construction, drilling operations (horizontal and vertical), hydraulic fracturing, extraction, transportation, and maintenance activities. The mere presence of humans, construction machinery, infrastructure (for example, well pads and pipelines), roads, and vehicles can substantially affect flora and fauna. Increased traffic, especially rapid increases on historically inactive roads, can detrimentally affect populations (Gibbs and Shriver, 2005). Forest loss, as a result of disturbance, fragmentation, and edge effects, negatively affects water quality and runoff (Wickham, and others, 2008), alters biosphere-atmosphere dynamics that could contribute to climate change (Hayden, 1998; Bonan, 2008), and affects even the long-term survival of the forest itself (Gascon and others, 2000). 


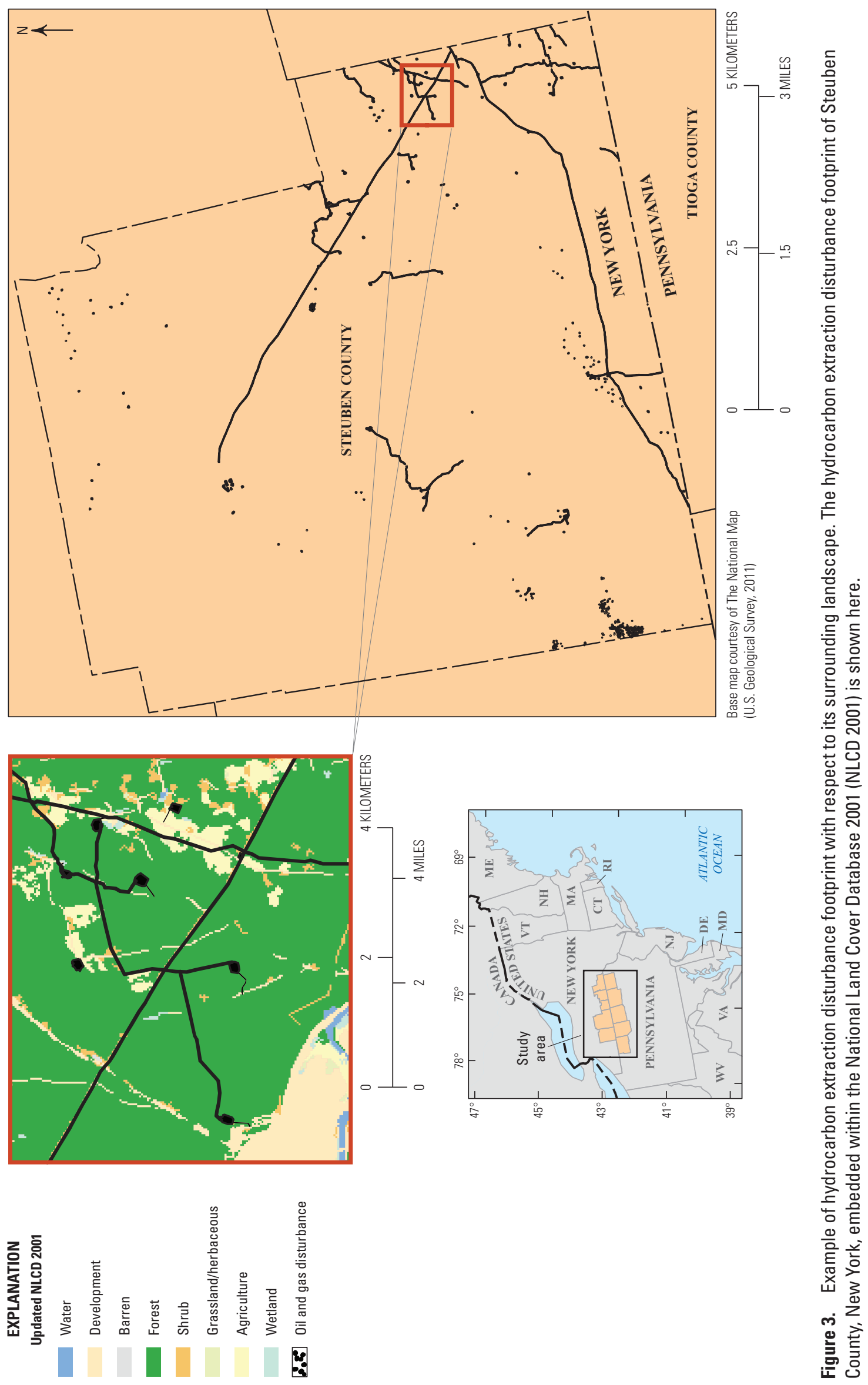




\section{Forest Fragmentation}

Fragmented forest and habitat are primary ecological concerns. Habitat fragmentation occurs when large areas of natural landscape are intersected and subdivided by other (usually anthropogenic) land uses, forcing smaller patches to become the habitat for species in that area. As human activities increase, natural habitats, such as forests, are divided into smaller and smaller patches, and these reduced areas have a decreased ability to support viable populations of individual species. Habitat loss and forest fragmentation can threaten biodiversity, although current research is inconclusive (With and Pavuk, 2011).

Many human and natural activities result in habitat fragmentation, but oil and gas development can be extreme in the degree to which it affects the landscape. Disturbances from well sites create holes in the natural landscape, and secondary roads and pipeline networks crisscross and subdivide surrounding habitat. Landscape disturbance associated with oil- and gas-extraction infrastructure alters habitat through land clearance (loss), fragmentation, and edge effects, which subsequently alter the flora and fauna dependent on the habitat. The fragmentation of habitat is expected to amplify the problem of areal habitat loss and increase habitat degradation. Fragmentation alters the landscape by creating a mosaic of spatially distinct habitats from initially contiguous habitat, which leads to smaller patch sizes, a higher number of patches, and decreased interior to edge ratios (Lehmkuhl and Ruggiero, 1991; Dale and others, 2000). Fragmentation often causes detrimental effects for flora and fauna because of increased mortality for individuals moving between patches, lower recolonization rates, and reduced local population sizes (Fahrig and Merriam, 1994). The remaining patches can be too small, too isolated, and possibly too influenced by edge effects to maintain viable populations of some species. The rate of landscape change can be more important than the amount or type of change because the temporal aspect of change can affect the probability of recolonization for endemic species, which are normally restricted by their dispersal range and the kinds of landscapes in which they can move (Fahrig and Merriam, 1994).

While assumptions and hypotheses are derived from the existing scientific literature, which involves similar stressors, the specific effects of habitat loss and fragmentation in the Marcellus Shale Play depend on the needs and attributes of specific species and communities. A recent analysis of Marcellus Shale well-permit locations in Pennsylvania found that the well pads and their common infrastructure (roads, water impoundments, and pipelines) required nearly 3.6 ha per well pad with an additional 8.5 ha of indirect edge effects (Johnson, 2010). This extensive and long-term habitat conversion has a more substantial effect on natural ecosystems than activities such as logging or agriculture. The effect results from the distinct dissimilarity between the gas-well pad infrastructure and adjacent natural areas, and from the low probability that the disturbed land can revert to a natural state in the near future, meaning that it would have to possess high persistence (Marzluff and Ewing, 2001).

\section{Interior Forest}

Interior forest is a unique form of forest habitat preferred by many plant and animal species. Interior forest is defined as an area of forest at least $100 \mathrm{~m}$ from the forest's edge (Harper and others, 2005). Interior forest is a vital landscape characteristic because the environmental conditions of light, wind, humidity, and exposure to predators are different within interior forest than for areas within forest edge. Interior forest habitat is related to the size and distribution of forest patches and tied to the concept of forest or habitat fragmentation: the alteration of habitat into smaller, less-functional areas. Interior forest area can be dramatically affected by linear land-use patterns, such as roads and pipelines, which create edges within the habitat and fragment larger habitat patches into smaller patches, thereby destroying habitat for certain species.

\section{Forest Edge}

Forest edge in a given location is a linear measure of the amount of edge between a forest area and other land-use areas. The edge between forests and human-dominated landscapes is of primary scientific interest. The influence that bordering landscapes have on each other is known as the edge effect and is observable for a distance from an edge (Skole and Tucker, 1993). The intensity of edge effects diminishes deeper inside the forest, but edge phenomena can vary between extremes for the same habitat fragment or landscape (Laurance and others, 2007). Factors that promote edge-effect variability include the edge age, the edge aspect, the proximity and number of nearby edges, fragment sizes, seasonality, and extreme weather events. Examples of these factors are (1) plots with two or more neighboring edges having higher tree mortality and biomass loss (Murcia, 1995); (2) over time, forest edge can be partially sealed by proliferating vines and secondary underbrush growth, which influence the ability of smaller tree seedlings to survive in this environment (Murcia, 1995); (3) forest edges adjoined by young regrowth forest provide a physical buffer from wind and light (Matlack, 1994); (4) abrupt, artificial boundaries of forest fragments are vulnerable to windstorms, snow and ice, and convectional thunderstorms that can weaken and destroy exposed forest edges (Laurance and others, 2007); and (5) periodic droughts can have a pronounced effect on forest edges exposed to drier wind conditions and higher rates of evaporation (Laurance and others, 2007). Due to computational limitations, this study reports forest edge as a distance $70 \mathrm{~m}$ or less from the forest edge. 


\section{Mapping and Measuring Disturbance Effects}

High-resolution aerial imagery of New York and Pennsylvania, acquired from the U.S. Department of Agriculture's National Agricultural Imagery Program for 2004-2013, was imported into GIS software, along with additional geospatial data on oil- and gas-drilling permits and the locations of State and county boundaries. The imagery was examined for distinct signs of disturbance related to oil and gas drilling and development; permit data were used for guidance. Observable features were manually digitized as line and polygon features in a GIS format. The polygons and line features were processed and aggregated by type of infrastructure-all (ALL), shale gas (SG), non-shale gas (NSG), other (O), oil (OIL), and pipeline (PL) - into raster masks to update existing land-cover data and are available from Roig-Silva and others (2019). Summary disturbance and land-cover statistics coupled with detailed landscape metrics for each five-county region (New York counties and Pennsylvania counties) and for each county, were developed and reported. For a full description of the methodology, see Slonecker and others (2012).

\section{Statistical Analysis}

All counties' changes in agricultural land and forest metrics, and percent oil and gas disturbance, expressed as a percentage of change at the county level, were evaluated using the Pearson correlation method. The Pearson correlation coefficient $\left(\mathrm{r}^{2}\right)$ ranges between +1 and -1 , where +1 indicates a perfect positive correlation between the variables and -1 indicates a perfect negative correlation. A coefficient of zero indicates no correlation. The statistical significance of the correlation $(p)$ is determined by the $\mathrm{r}^{2}$ value and the degrees of freedom (number of observations minus 2).

\section{Permits}

Data pertaining to the location of the developed and undeveloped permits obtained and compiled from each State's database for this study are shown in figure 4. Permits lacking locational information were removed, and this process revealed that many permits are undeveloped. Figure 5 lists State totals for all permits and sites, and it also indicates the type of permit (such as shale gas or non-shale gas). The "other" category includes permits for wells other than the types mentioned above, such as injection-well permits. The "other" category also includes sites that were identified but lacked a permit within a 250 -m buffer radius. The 250-m buffer radius was the distance selected based on the observations found in Pennsylvania permits (Slonecker and others, 2012). Although the New York Department of Environmental Conservation's data show that the permits are not field verified and are expected to be within a 91-m buffer (New York State Department of Environmental Conservation, 2015c), the 250-m buffer distance was kept maintaining consistency with previously published work.

The use of a $250-\mathrm{m}$ buffer to identify permits associated with a site caused multiple permits to be assigned to some sites but reduced the number of sites identified as "other" due to the lack of a permit. Most disturbance types have less than half the number of sites as permits with two exceptions: non-shale gas in New York and "other" in Pennsylvania (fig. 5). Developed non-shale gas sites in New York have almost four times the number of permits, indicating that other sites, presumably oil sites, were also identified as non-shale gas due to the concentrated permit placement for such sites (fig. 5). Pennsylvania has more than 10,000 more drilling permits than drilling sites, with the majority consisting of oil and non-shale gas permits.

\section{Results}

\section{Disturbance}

The disturbance area in the Pennsylvania region was over three times that of the New York region and was distributed over almost three times as many sites (table 1). The major difference between the areas stems from the greater development of shale gas sites in the Pennsylvania region, which has almost 60 times as many shale gas sites as the New York region and averages 3.4 ha of total disturbance per site, whereas the New York sites average 1.7 ha of total disturbance per site. This difference is then indicated by the comparison of approximately 4,910 ha of total shale-gas disturbance in the Pennsylvania region to approximately 43 ha of total shale-gas disturbance in the New York region.

As noted previously, disturbance from Pennsylvania shale-gas sites is, on average, greater than disturbance from New York shale-gas sites (fig. 6). Mean disturbance per site area for the remaining types of infrastructure is more similar. The values of mean disturbance per site area in New York counties are highly variable, whereas the values of mean disturbance per site in Pennsylvania counties are similar, except for those in McKean County, which contains mostly small oil and non-shale gas sites. Several counties have high values of disturbance per site under all infrastructure because pipeline disturbance is included. 


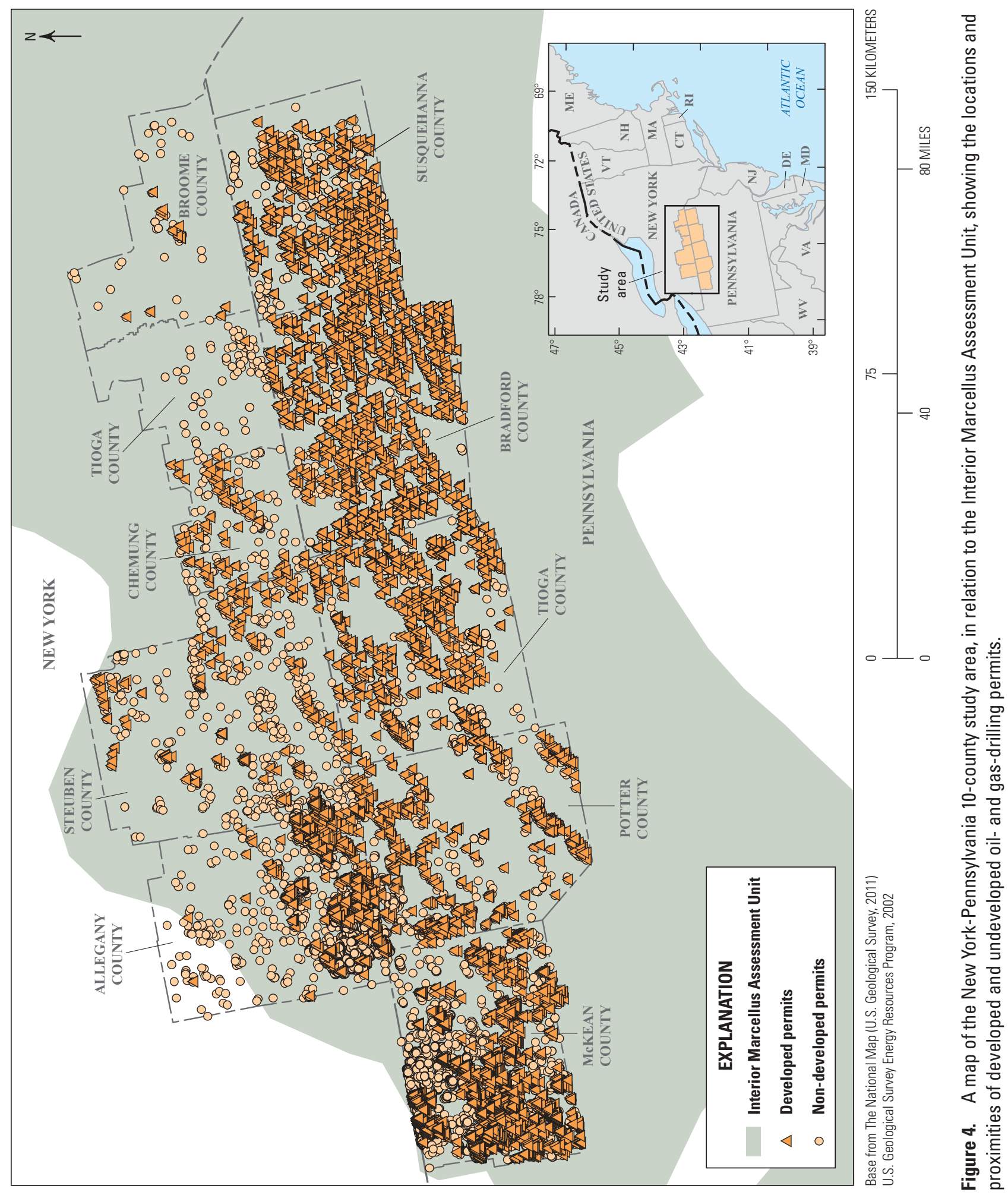




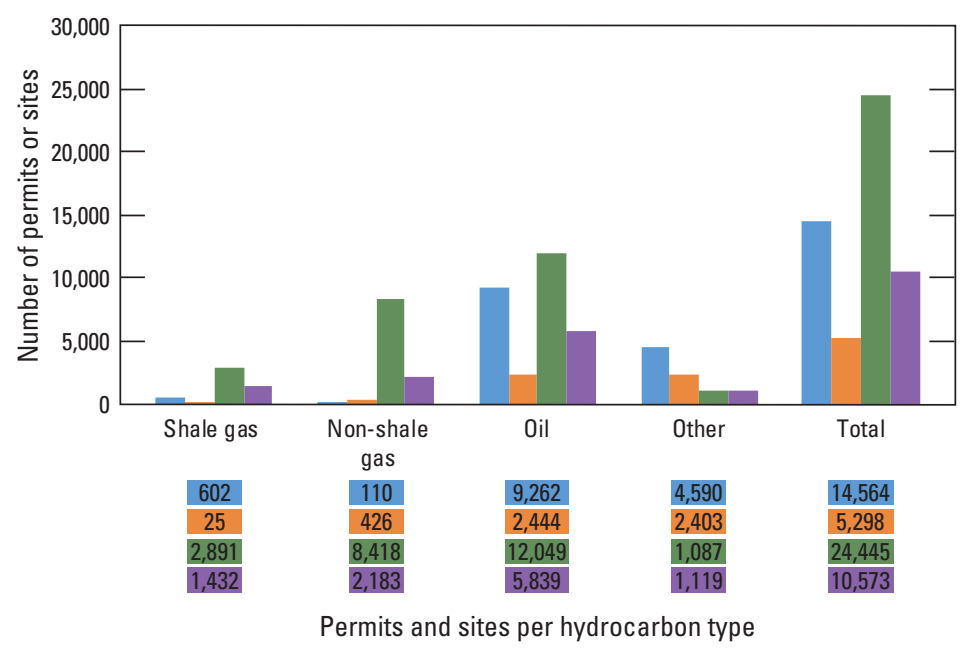

EXPLANATION

New York drilling permits

New York drilling sites

Pennsylvania drilling permit

Pennsylvania drilling sites

Figure 5. A bar graph comparing oil- and gas-drilling permits to developed sites for the hydrocarbon types discussed in this study — shale gas, non-shale gas, oil, and other-for the New York and Pennsylvania five-county regions.

Table 1. Disturbance summary statistics for New York and Pennsylvania counties. "Hectares per site" is the mean area for sites only, whereas "Disturbed hectares per site" accounts for the area used for roads and pipelines in the mean. Because of multiple permits per site, columns and rows do not sum as expected.

[ha, hectares; -, not applicable.]

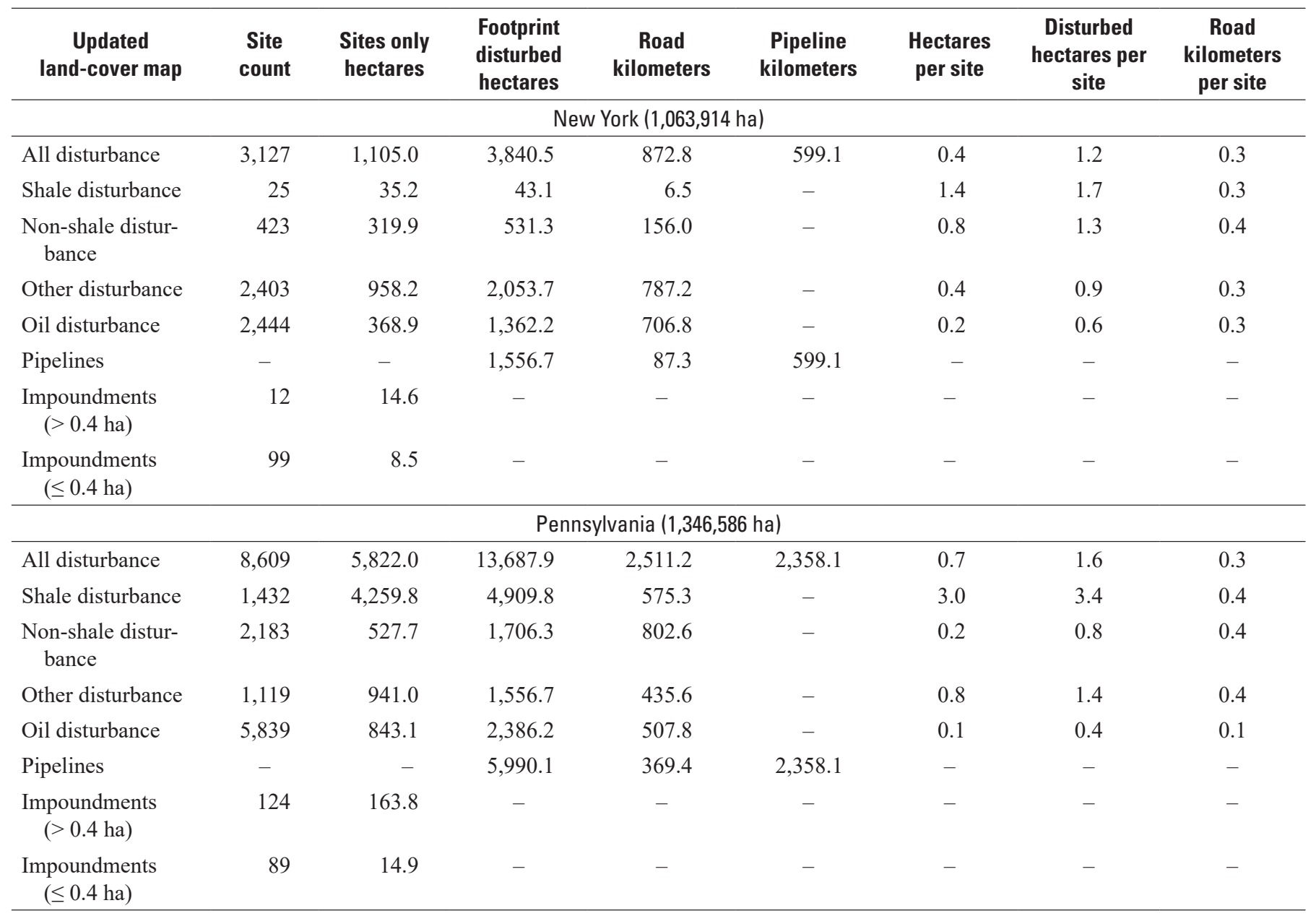




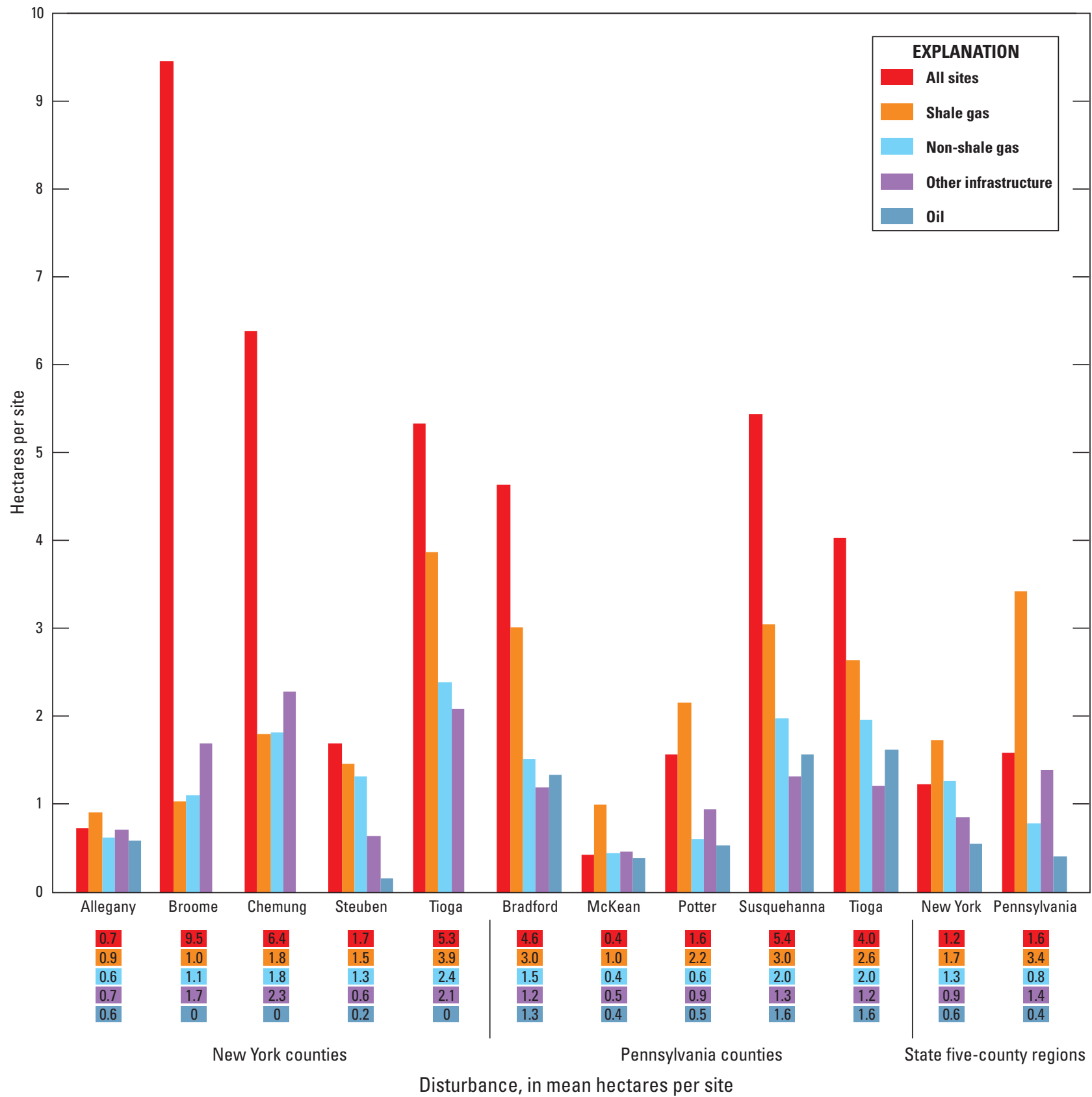

Figure 6. Bar graphs showing mean oil- and gas-development disturbance, in hectares per site. Disturbance is shown by type of site-oil, other infrastructure, non-shale gas, shale gas, and all sites-for each of the counties in the five-county New York and Pennsylvania regions and each State's five-county study region. Note that the disturbance per site for "all sites" includes pipelines, whereas the specific oil- and gas-development types do not, resulting in unexpected values. 


\section{Land-Use and Land-Cover Change}

Forest and agricultural land are the two LULC classes most affected in both the New York and Pennsylvania five-county regions. A higher percentage of loss in land cover and total land area, for both classes, occurred in Pennsylvania than occurred in New York. For all 10 counties (individually) and each five-county region, almost twice the amount of forest was lost when compared to the amount of agricultural land lost as a result of total hydrocarbon development (fig. 7; table 2). When LULC change is examined by hydrocarbon-development type (oil, shale gas, or non-shale gas), agricultural land loss only exceeds forest loss for shale gas in Pennsylvania (table 2), specifically in Bradford and Susquehanna Counties, which are areas of substantial shale-gas disturbance (fig. 8).

Bradford, McKean, and Susquehanna Counties in Pennsylvania have the highest percentage (1.4-1.5 percent) of oil and gas development (fig. 8). McKean County oil and gas development was primarily from oil and, to a lesser extent, non-shale gas; Bradford and Susquehanna Counties' oil and gas disturbance was from shale gas and pipeline infrastructure. Allegany and Chemung Counties in New York have a moderate (0.6- 0.7 percent) percentage of oil and gas disturbance. The remaining counties have less than 0.4 percent oil and gas development.

McKean County, Pa., sustained the highest percentage of forest loss (-1.0 percent; fig. 8). Allegany County, N.Y., and Bradford and Susquehanna Counties, Pa., had about half of McKean County's loss ( -0.5 percent, -0.5 percent, and -0.6 percent, respectively), while the remaining counties had relatively small losses of forest ( -0.3 percent or less; fig. 8 ).

Bradford and Susquehanna Counties, Pa., sustained the highest percentage of agricultural land lost to oil and gas disturbance ( -0.8 percent and -0.6 percent, respectively; fig. 8), and Allegany County, N.Y., Chemung County, N.Y., and Tioga County, Pa., sustained a smaller percentage of agricultural land loss, about -0.2 percent each. The remaining counties lost less than 0.2 percent of agricultural land to oil and gas disturbance.

\section{Forest Metrics}

Results obtained by ATtILA suggest that disturbance from shale-gas sites affects forest land the least, while oil and pipelines affect it the most (table 3; fig. 9). McKean County, Pa., underwent the most changes in all forest metrics (percent forest, percent forest edge, and percent interior forest; fig. 10); the percent forest presented in this section is an ATtILA calculation of forest type identified as interior, edge, patch, perforated, and transitional (Riitters and others, 2000; Ebert and Wade, 2004). Of the forest metrics measured, forest interior was the most affected in McKean County, Pennsylvania.

\section{Relationship of Oil and Gas Development to Land-Use and Land-Cover Change}

Pearson correlation coefficient results indicate that changes in the percentages of forest and agricultural land strongly correlate with disturbance from oil and gas development across the study area and each State's five-county region (table 4). Five of the six land use/land cover metrics analyzed for the New York counties, show statistical significance. These include changes in percent forest (LULC); a combination of changes in both percent forest and agriculture; percent forest; percent forest edge; and percent interior forest. On the other hand, in Pennsylvania, only one of these metrics - combined change in percent forest and agricultural land -was statistically significant.

\section{Discussion}

Forest and agricultural land are the major LULC classes in the region and experienced the most change from oil and gas development. Forest underwent about twice as much disturbance as agricultural land. LULC change from hydrocarbon development in the New York-Pennsylvania study area strongly correlates with a decrease in the percentages of forest and agricultural land-cover classes. Most of the more than 17,000 ha disturbed were forest $(-0.2$ percent or $2,127.8$ ha in New York; -0.5 percent or $6,732.9$ ha in Pennsylvania) and agricultural land ( -0.1 percent or 1,063.9 ha in New York; -0.3 percent or $4,039.8$ ha in Pennsylvania; table 2). At the five-county region level, the correlation breaks down. LULC change from hydrocarbon development in New York strongly correlates with forest and forest metrics, but in Pennsylvania, there is no correlation between hydrocarbon development and either forest or agricultural land. The difference in correlation measurements between the five-county regions could be attributed to the use of all hydrocarbon development types, although development types differ by region. New York's hydrocarbon development consists primarily of non-shale sources developed in forests, while Pennsylvania's hydrocarbon development includes a large number of shale sites developed primarily on agricultural land. This interpretation is supported by observing that the most significant change in forest structure and area occurred in McKean County, Pa., a county with extensive oil and non-shale gas development.

In the New York-Pennsylvania 10-county region, oil and gas development disturbs mainly forest and agricultural land cover with measurable effects on interior forest and forest edge. The disturbance and its effects are also shown for the New York and Pennsylvania five-county regions, although the region in New York experienced about half the amount of oil and gas development as the Pennsylvania region. 
Compared with the Pennsylvania region, the New York region has a smaller percentage of land disturbed by oil and gas development. The New York moratorium on hydraulic fracturing for shale gas is likely to have played a part in the smaller disturbance level, although the shale-gas resource could be reduced in the New York portion of the Marcellus Shale Assessment Unit. On the other hand, Pennsylvania has no prohibition on hydraulic fracturing, which has allowed the extensive development of shale-gas resources, especially in Bradford and Susquehanna Counties: a so-called "sweet-spot" for shale gas development (Stevens and Kuuskraa, 2009).

Landscape disturbance results directly from oil and gas development, although the pattern of disturbance varies by location and the type of oil and (or) gas under development. An alternate pattern of disturbance can be seen in (1) McKean County, Pa., and Allegany County, N.Y., primarily from oil development, and (2) Bradford and Susquehanna Counties, Pa., from shale-gas development (fig. 11). Shale-gas sites usually have a substantial disturbance footprint and are more dispersed, while the smaller, non-shale gas and oil sites are seven times more numerous than shale-gas sites and frequently tend to occur in clusters.

Pennsylvania lost the most land cover (forest and agricultural land), with four out of five counties ranking in the highest class of loss (more than 0.50 percent loss; fig. 12); New York lost the least, with three out of five counties in the lowest class of loss (less than 0.35 percent loss). Bradford, McKean, and Susquehanna Counties in Pennsylvania sustained the greatest loss of those land-cover classes, but when considering forest and agricultural land separately, McKean County sustained the greatest forest loss, and Bradford County sustained the greatest agricultural land loss. Bradford County is a center of shale-gas production while McKean County is a center of oil and non-shale gas production.
A closer examination of the bar charts for the counties (fig. 12) reveals that McKean County sustained the greatest change in forest metrics through a substantial increase in forest edge and an even greater decrease in interior forest from oil and non-shale gas development. These two forest-condition metrics indicate that changes in the forest structure could have implications for ecological processes and species habitat. Similar, although lesser, changes are observed in Allegany County, N.Y., and in Bradford and Susquehanna Counties, Pa., all of which have more agricultural land than McKean County.

Hydrocarbon development and disturbance in the New York-Pennsylvania 10-county border region affected less than 1 percent of the landscape, primarily among forest and agricultural land cover (table 5). While each type of hydrocarbon development (shale gas, non-shale gas, and oil) has a distinctive presence on the landscape and affects metrics in different ways, each development type produces landscape change.

While sites were successfully identified as oil and gas development in Pennsylvania and New York by their physical characteristics, the identification of their development type (shale gas, non-shale gas, or oil) was problematic. Limitations on user-supplied information on oil- and gas-drilling permit locations, and therefore well type, impeded efforts to accurately identify the development type for many site polygons. The technique used in the study resulted in some polygons having erroneous or multiple permit types but also limited the number of oil and gas sites identified as "other." These errors are likely dependent on the dispersion of wells of the same type, the intermixing of wells of differing types, and permitdatabase accuracy. The land-cover maps calculated for the well subtypes (shale gas, non-shale gas, and oil) and, hence, 


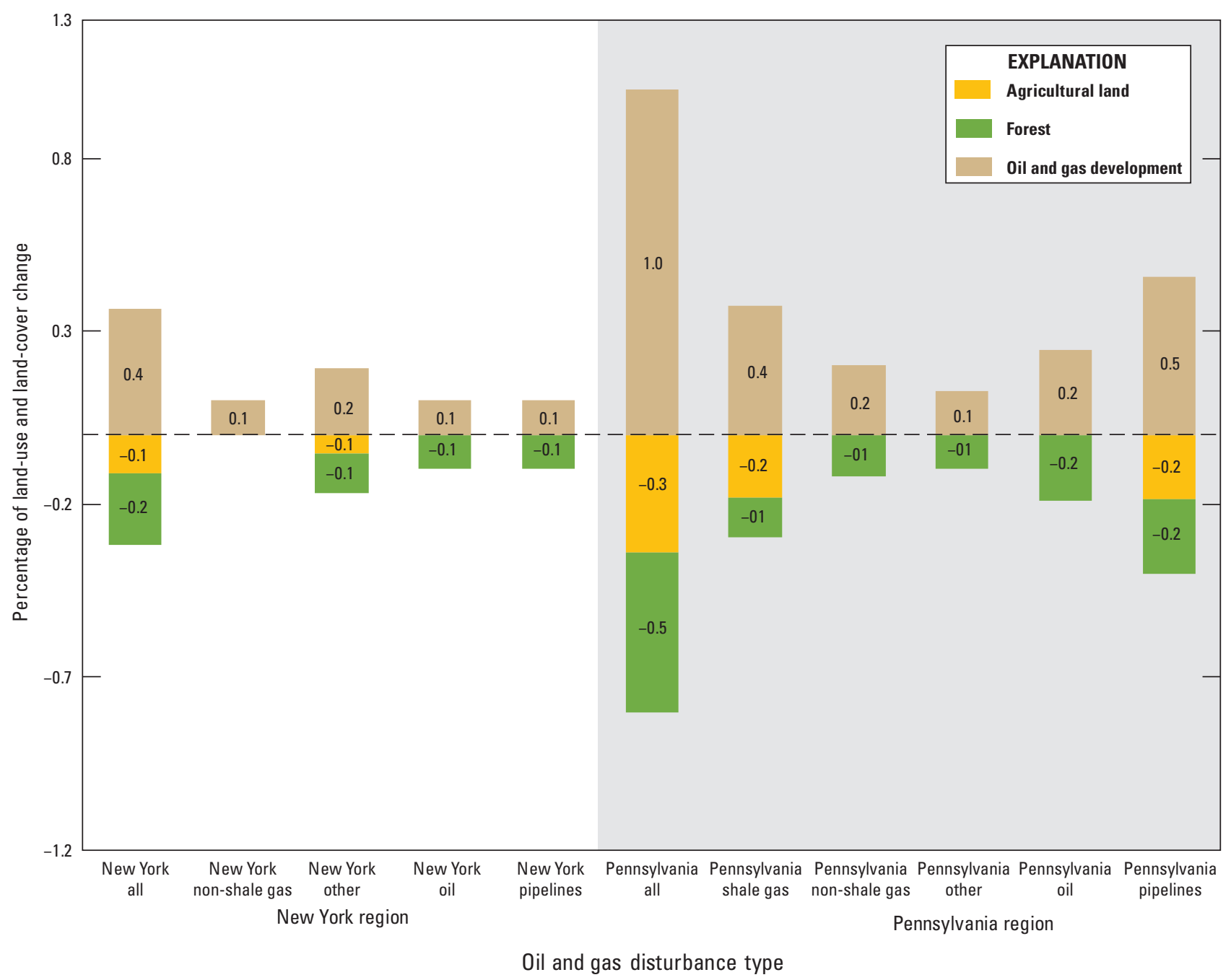

Figure 7. Bar graph showing percentages of forest and agricultural land lost compared with percentages of oil and gas development in New York and Pennsylvania counties. Oil- and gas-development types are given separately for each State. 
Table 2. Complete land-use and land-cover change details from oil and gas development for the New York five-county region of the study and the Pennsylvania five-county region of the study. Area data are from the 2001 edition of the National Land Cover Database (NLCD 2001).

[ha, hectares]

\begin{tabular}{|c|c|c|c|c|c|c|c|c|}
\hline \multirow{2}{*}{$\begin{array}{l}\text { Land-cover } \\
\text { class }\end{array}$} & \multicolumn{2}{|c|}{ Original NLCD 2001} & \multirow{2}{*}{$\begin{array}{c}\text { Percent } \\
\text { change } \\
\text { from all } \\
\text { disturbance }\end{array}$} & \multirow{2}{*}{$\begin{array}{c}\text { Percent } \\
\text { change from } \\
\text { shale gas } \\
\text { disturbance }\end{array}$} & \multirow{2}{*}{$\begin{array}{c}\text { Percent } \\
\text { change from } \\
\text { non-shale gas } \\
\text { disturbance }\end{array}$} & \multirow{2}{*}{$\begin{array}{c}\text { Percent } \\
\text { change } \\
\text { from other } \\
\text { disturbance }\end{array}$} & \multirow{2}{*}{$\begin{array}{c}\text { Percent } \\
\text { change } \\
\text { from oil } \\
\text { disturbance }\end{array}$} & \multirow{2}{*}{$\begin{array}{c}\text { Percent } \\
\text { change from } \\
\text { pipeline } \\
\text { disturbance }\end{array}$} \\
\hline & Area, ha & $\begin{array}{c}\text { Area, } \\
\text { percentage }\end{array}$ & & & & & & \\
\hline \multicolumn{9}{|c|}{ New York $(1,063,914$ ha) } \\
\hline Forest & $644,188.3$ & 60.5 & -0.2 & 0.0 & 0.0 & -0.1 & -0.1 & -0.1 \\
\hline $\begin{array}{l}\text { Agricultural } \\
\text { land }\end{array}$ & $296,403.4$ & 27.9 & -0.1 & 0.0 & 0.0 & -0.1 & 0.0 & 0.0 \\
\hline Developed land & $62,462.6$ & 5.9 & 0.0 & 0.0 & 0.0 & 0.0 & 0.0 & 0.0 \\
\hline $\begin{array}{l}\text { Grassland- } \\
\text { herbaceous }\end{array}$ & $5,059.4$ & 0.5 & 0.0 & 0.0 & 0.0 & 0.0 & 0.0 & 0.0 \\
\hline Water & $9,288.6$ & 0.9 & 0.0 & 0.0 & 0.0 & 0.0 & 0.0 & 0.0 \\
\hline Barren & $1,301.3$ & 0.1 & 0.0 & 0.0 & 0.0 & 0.0 & 0.0 & 0.0 \\
\hline Wetlands & $18,888.2$ & 1.8 & 0.0 & 0.0 & 0.0 & 0.0 & 0.0 & 0.0 \\
\hline Scrub-shrub & $26,320.4$ & 2.5 & 0.0 & 0.0 & 0.0 & 0.0 & 0.0 & 0.0 \\
\hline $\begin{array}{c}\text { Gas extraction } \\
\text { disturbance }\end{array}$ & 0.0 & 0.0 & 0.4 & 0.0 & 0.1 & 0.2 & 0.1 & 0.1 \\
\hline \multicolumn{9}{|c|}{ Pennsylvania (1,346,586 ha) } \\
\hline Forest & $911,159.3$ & 67.7 & -0.5 & -0.1 & -0.1 & -0.1 & -0.2 & -0.2 \\
\hline $\begin{array}{l}\text { Agricultural } \\
\text { land }\end{array}$ & $289,633.2$ & 21.5 & -0.3 & -0.2 & 0.0 & 0.0 & 0.0 & -0.2 \\
\hline Developed land & $47,698.5$ & 3.5 & 0.0 & 0.0 & 0.0 & 0.0 & 0.0 & 0.0 \\
\hline $\begin{array}{l}\text { Grassland- } \\
\text { herbaceous }\end{array}$ & $6,896.2$ & 0.5 & 0.0 & 0.0 & 0.0 & 0.0 & 0.0 & 0.0 \\
\hline Water & $7,676.0$ & 0.6 & 0.0 & 0.0 & 0.0 & 0.0 & 0.0 & 0.0 \\
\hline Barren & $3,317.8$ & 0.2 & 0.0 & 0.0 & 0.0 & 0.0 & 0.0 & 0.0 \\
\hline Wetlands & $30,687.9$ & 2.3 & 0.0 & 0.0 & 0.0 & 0.0 & 0.0 & 0.0 \\
\hline Scrub-shrub & $49,509.5$ & 3.7 & -0.1 & 0.0 & 0.0 & 0.0 & 0.0 & 0.0 \\
\hline $\begin{array}{c}\text { Gas extraction } \\
\text { disturbance }\end{array}$ & 0.0 & 0.0 & 1.0 & 0.4 & 0.2 & 0.1 & 0.2 & 0.5 \\
\hline
\end{tabular}




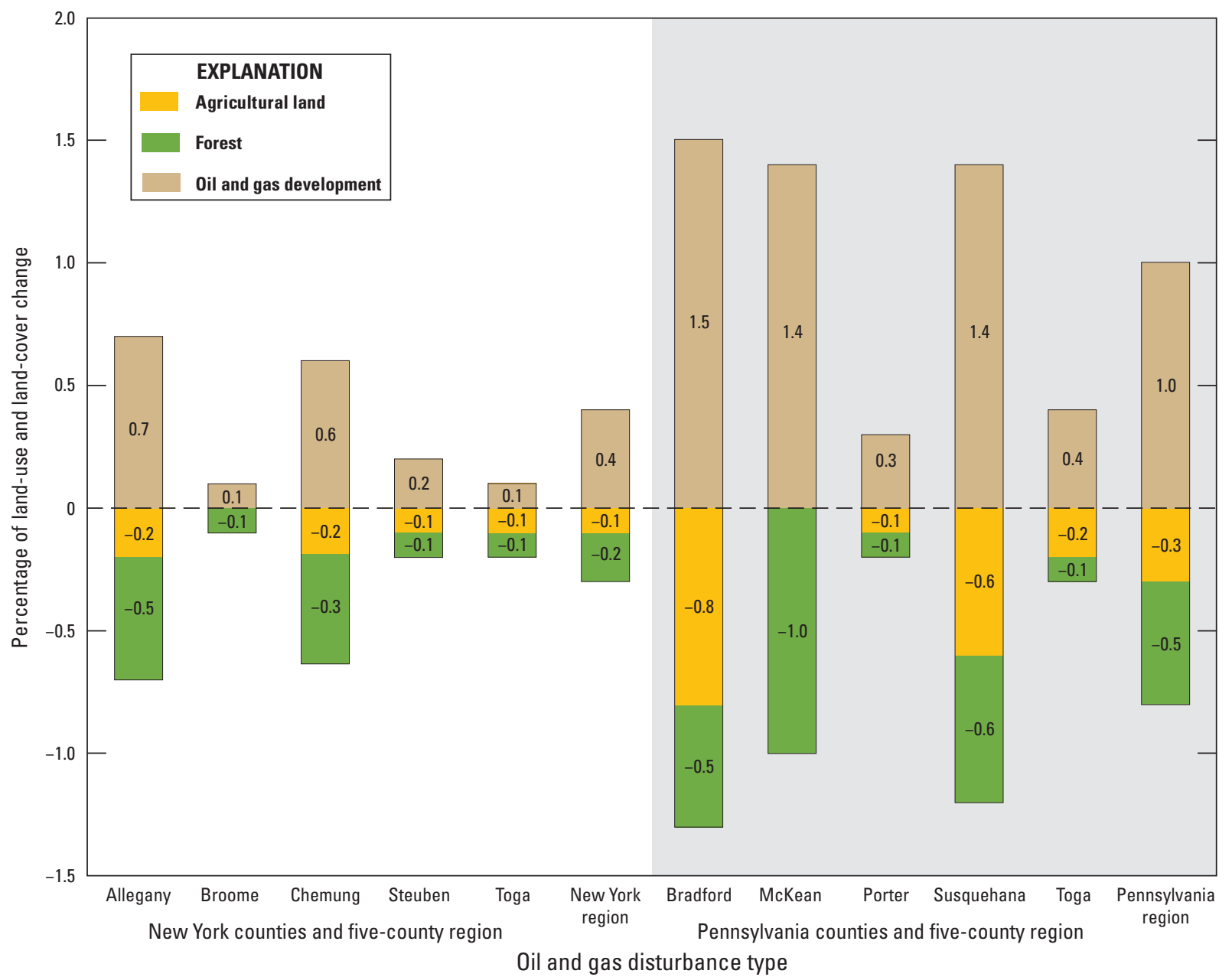

Figure 8. Bar graph showing percentages of land-use and land-cover change, by county and five-county region, for agricultural land, forest, and oil and gas development in New York and Pennsylvania.

Table 3. Forest area metrics for the New York and Pennsylvania five-county regions.

[Because of multiple permits per site, columns and rows do not sum as expected.]

\begin{tabular}{|c|c|c|c|c|c|c|c|}
\hline Infrastructure & $\begin{array}{l}\text { Original } \\
\text { land } \\
\text { cover, in } \\
\text { percent }\end{array}$ & $\begin{array}{l}\text { Change from } \\
\text { all oil and gas } \\
\text { disturbance, in } \\
\text { percent }\end{array}$ & $\begin{array}{l}\text { Change from } \\
\text { shale gas } \\
\text { disturbance, in } \\
\text { percent }\end{array}$ & $\begin{array}{c}\text { Change from } \\
\text { non-shale gas } \\
\text { disturbance, in } \\
\text { percent }\end{array}$ & $\begin{array}{c}\text { Change } \\
\text { from other } \\
\text { disturbance, in } \\
\text { percent }\end{array}$ & $\begin{array}{c}\text { Change from oil } \\
\text { disturbance, in } \\
\text { percent }\end{array}$ & $\begin{array}{c}\text { Change from } \\
\text { pipeline } \\
\text { disturbance, in } \\
\text { percent }\end{array}$ \\
\hline \multicolumn{8}{|c|}{ New York regional disturbance } \\
\hline Forest & 61.1 & -0.2 & 0.0 & 0.0 & -0.1 & -0.1 & -0.1 \\
\hline Interior forest & 43.8 & -0.7 & 0.0 & -0.1 & -0.4 & -0.3 & -0.3 \\
\hline \multicolumn{8}{|c|}{ Pennsylvania regional disturbance } \\
\hline Forest & 68.0 & -0.5 & -0.1 & -0.1 & -0.1 & -0.1 & -0.2 \\
\hline Interior forest & 51.4 & -1.6 & -0.2 & -0.5 & -0.2 & -0.7 & -0.7 \\
\hline Forest edge & 12.7 & 0.9 & 0.1 & 0.3 & 0.1 & 0.4 & 0.4 \\
\hline
\end{tabular}


Discussion

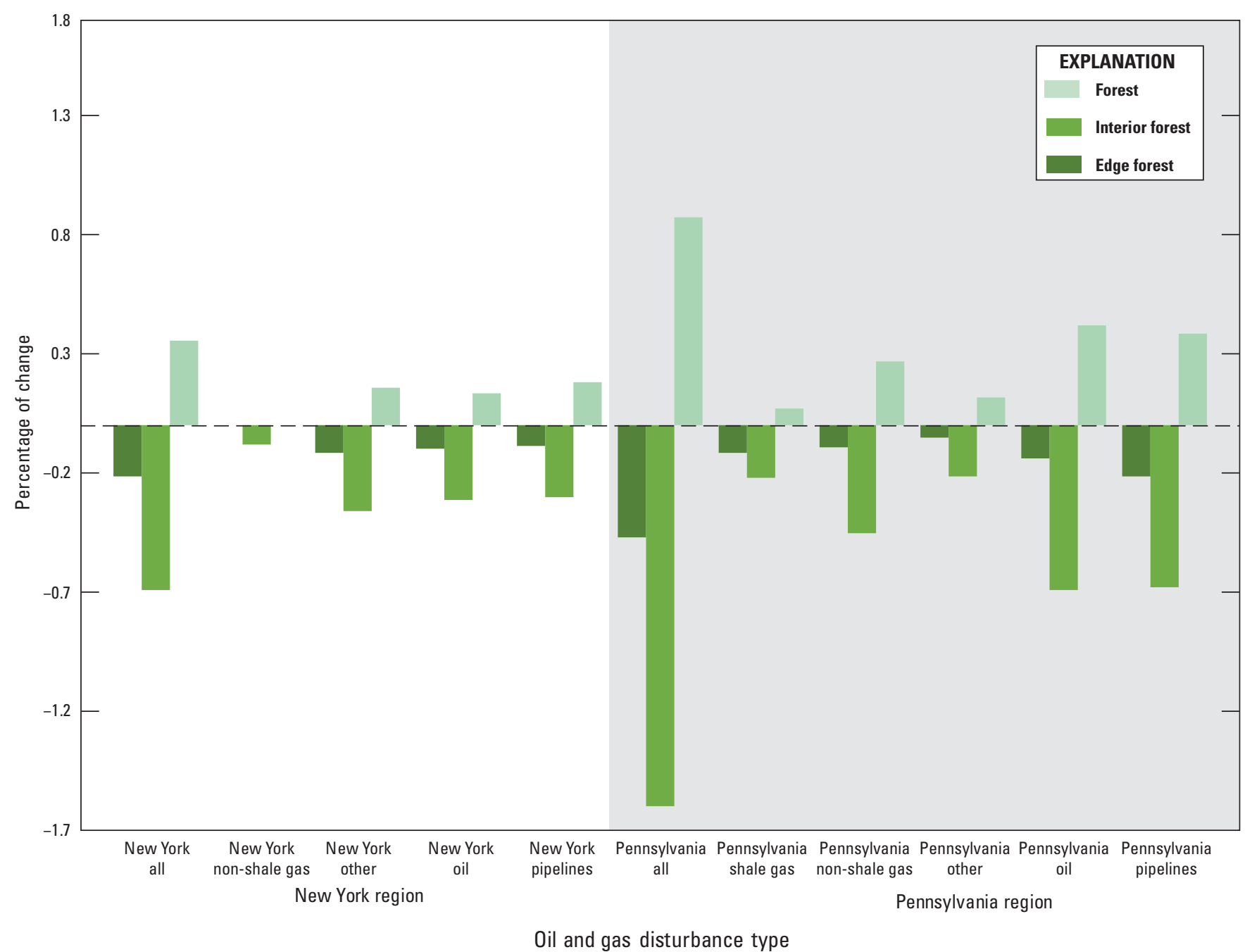

Figure 9. Bar graph showing percentages of forest change caused by oil- and gas-development disturbance in the five-county New York and Pennsylvania regions. Changes in each State are given for forest, interior forest, and forest edge by development-site type. 


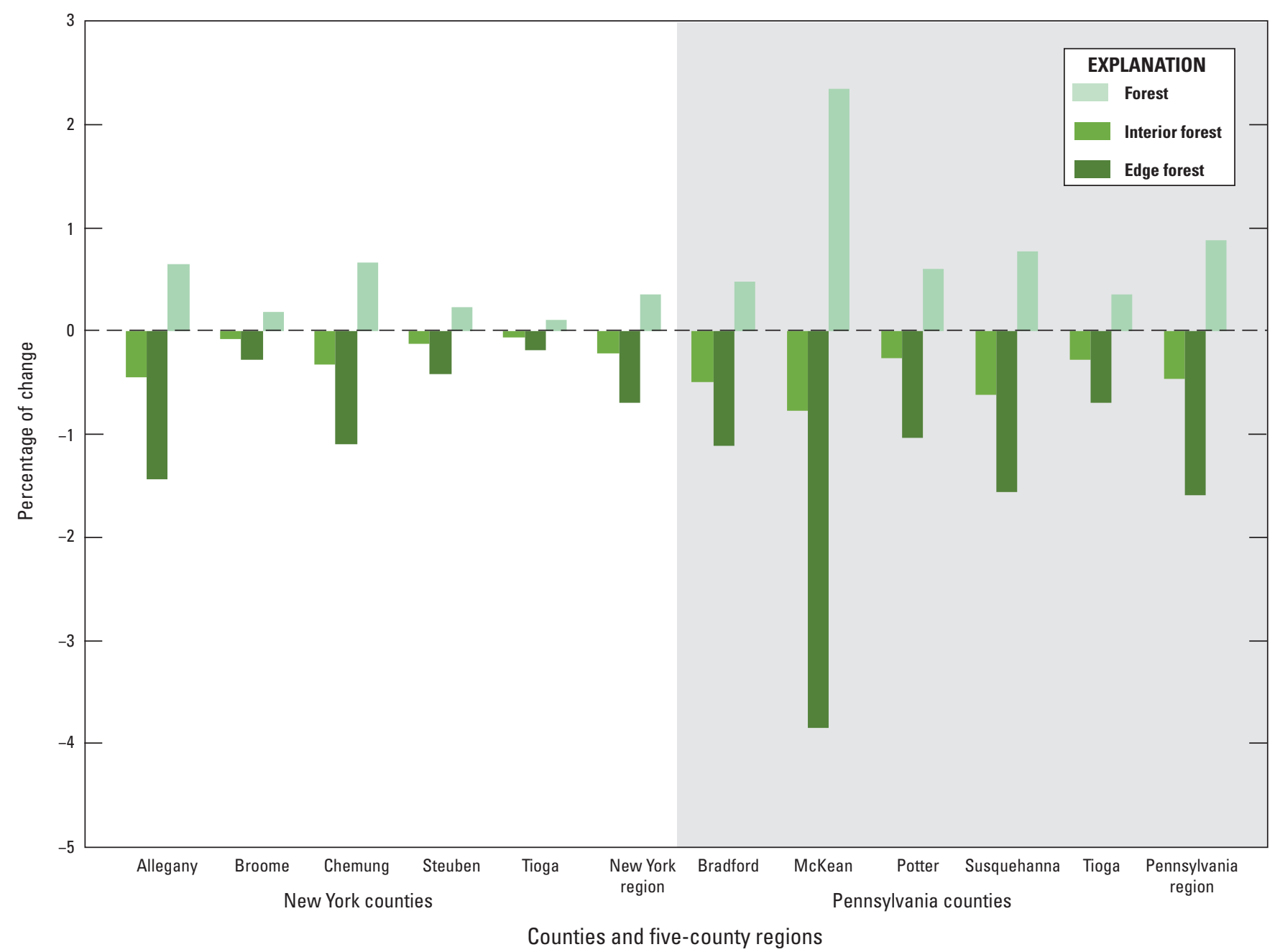

Figure 10. Bar graph showing the percentage of forest change by type (percent forest, percent interior forest, percent forest edge) for each county and each five-county region in the study, grouped by State.

Table 4. Summary of the Pearson correlation coefficient for changes in metrics-for the entire 10-county region, the New York counties in the study, and the Pennsylvania counties in the study—shown as statistical significance levels.

[ $\mathrm{r}^{2}$, Pearson correlation coefficient; $\mathrm{p}$, statistical significance; $n s$, no significance]

\begin{tabular}{|c|c|c|c|c|c|c|}
\hline \multirow{2}{*}{ Change in metric } & \multicolumn{2}{|c|}{ 10-county region } & \multicolumn{2}{|c|}{ New York } & \multicolumn{2}{|c|}{ Pennsylvania } \\
\hline & $\mathbf{r}^{2}$ & $\mathbf{p}$ & $\mathbf{r}^{2}$ & $\mathbf{p}$ & $\mathbf{r}^{2}$ & $\mathbf{p}$ \\
\hline Percent agricultural land & 0.521 & $\mathrm{~ns}$ & 0.701 & ns & 0.362 & $\mathrm{~ns}$ \\
\hline Percent forest and agricultural land & 0.993 & 0.01 & 0.996 & 0.01 & 0.989 & 0.01 \\
\hline Percent forest & 0.835 & 0.01 & 0.970 & 0.01 & 0.714 & ns \\
\hline
\end{tabular}

${ }^{1}$ Percent forest is listed twice in table 3: the first occurrence is the percentage of land cover classified as forest, and the second is an Analytical Tools Interface for Landscape Assessments (ATtILA) calculation of forest type identified as interior, edge, patch, perforated, and transitional (Riitters and others, 2000; Ebert and Wade, 2004). 


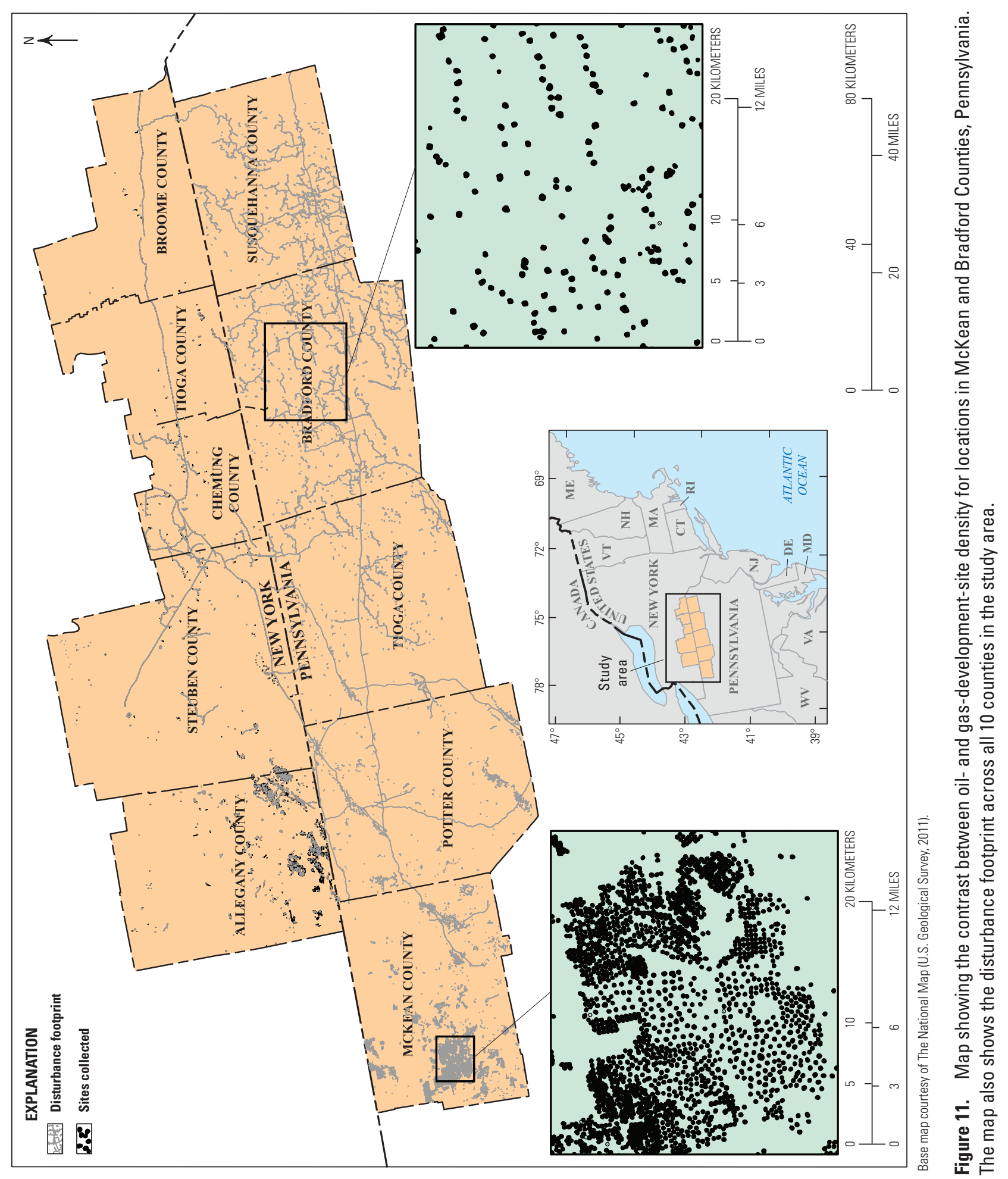




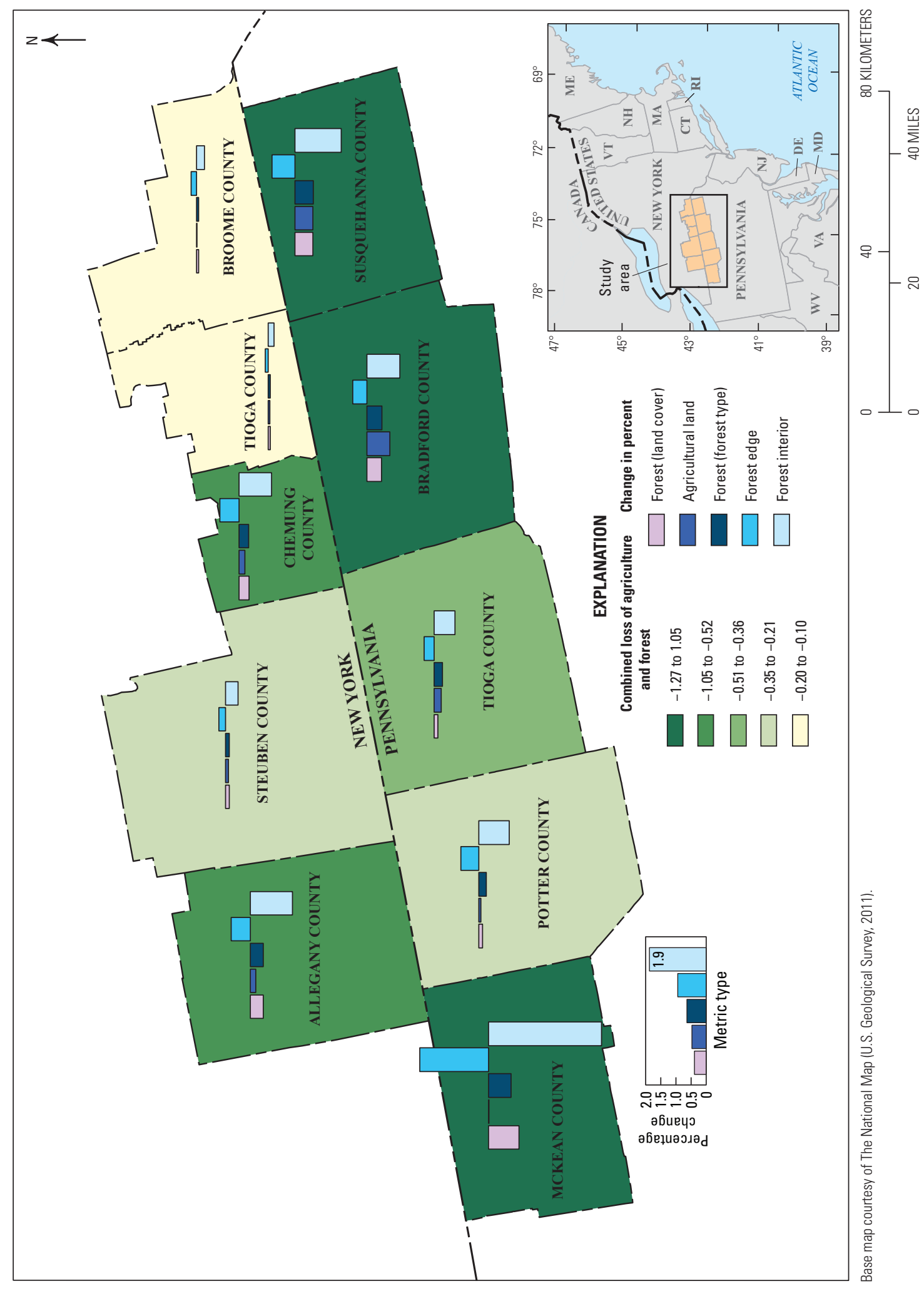

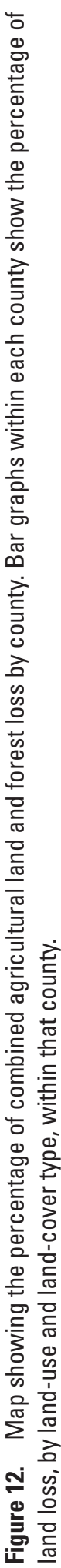


Table 5. Summary of regional land-use and land-cover change for each New York and Pennsylvania five-county region, and for the entire 10-county region, from oil and gas development.

\begin{tabular}{lcccccc}
\hline \multicolumn{1}{c}{ Region } & $\begin{array}{c}\text { Area in } \\
\text { hectares }\end{array}$ & $\begin{array}{c}\text { Percent oil and } \\
\text { gas disturbance }\end{array}$ & $\begin{array}{c}\text { Change in } \\
\text { percent } \\
\text { agricultural land }\end{array}$ & $\begin{array}{c}\text { Change in } \\
\text { percent forest }\end{array}$ & $\begin{array}{c}\text { Change in } \\
\text { percent } \\
\text { interior forest }\end{array}$ & $\begin{array}{c}\text { Change in } \\
\text { percent forest } \\
\text { edge }\end{array}$ \\
\hline $\begin{array}{l}\text { New York-Pennsylvania } \\
\quad \text { 10-county region }\end{array}$ & $2,410,500$ & 0.7 & -0.2 & -0.4 & -1.2 & 0.7 \\
New York five-county region & $1,063,914$ & 0.4 & -0.1 & -0.2 & -0.7 & 0.4 \\
$\begin{array}{l}\text { Pennsylvania five-county } \\
\text { region }\end{array}$ & $1,346,586$ & 1.0 & -0.3 & -0.5 & -1.6 & 0.9 \\
\hline
\end{tabular}

the metrics calculated from them, are subject to an unspecified amount of error. The "all" infrastructure category does not have this limitation.

\section{Conclusions}

The goal of this study was to identify the level of hydrocarbon-development disturbance in a 10-county region along the New York-Pennsylvania border and articulate (1) how the landscape has changed from this development and (2) potential effects on forest structure. Overall, oil- and gasdevelopment disturbance is a small percentage ( 0.4 percent in New York; 1.0 percent in Pennsylvania), but it equates to a substantial amount of land area $(4,255.7$ ha in New York; 13,465.9 ha in Pennsylvania). Two components compose the difference in disturbance: shale gas development and an extensive pipeline system in Pennsylvania. Across the region, almost half of the disturbance can be attributed to pipelines, many of which were constructed decades ago but are subject to maintenance and connection to newly developed oil and gas sites. The remaining disturbance differs by region. Disturbance in the Pennsylvania five-county region is primarily from oil and shale-gas development, whereas the New York five-county region is disturbed by oil and "other" development. The "other" category includes storage and injection wells, pipeline control structures, and erroneously classified sites.

Land-use and land-cover changes were mostly concentrated in forested areas in New York, while Pennsylvania experienced changes in both agricultural land and forested lands. This study found that forest loss was greater than agricultural land loss.

Forest loss was mostly affected by forest structure. Forest loss led to approximately three times the loss of interior forest and a doubling of forest edge area. Of the 10-conty region, McKean County in Pennsylvania suffered the greatest changes in interior forest and forest edge. Although beyond the scope of this report, changes in forest structure are associated with adverse effects in ecosystems and ecosystem services they provide. Further investigation in understanding these changes in land use and land cover and its effects are needed to better assess possible effects of oil and gas extraction in the area.

Limitations in the permit database and the lack of field validation for the identified sites, and the fact that the study area has been subject to hydrocarbon exploration for many years makes it difficult to separate the effects of oil and gas extraction individually.

\section{References Cited}

Bonan, G.B., 2008, Forest and climate change-Forcings, feedbacks, and the climate benefits of forests: Science, v. 320 , no. 5882 , p. 1444-1449, accessed May 10, 2018, at https://doi.org/10.1126/science.1155121.

Coleman, J.L., Milici, R.C., Cook, T.A., Charpentier, R.R., Kirschbaum, M., Klett, T.R., Pollastro, R.M., and Schenk, C.J., 2011, Assessment of undiscovered oil and gas resources of the Devonian Marcellus shale of the Appalachian Basin province, 2011: U.S. Geological Survey Fact Sheet 2011-3092, 2 p., accessed November 17, 2011, at https://pubs.usgs.gov/fs/2011/3092/.

Dale, V.H., Brown, S., Haeuber, R.A., Hobbs, N.T., Huntly, N., Naiman, R.J., Riebsame, W.E., Turner, M.G., and Valone, T.J., 2000, Ecological principles and guidelines for managing the use of land-Ecological Society of America report: Ecological Applications, v. 10, no. 3, p. 639-670. [Also available at https://doi.org/10.2307/2641032.].

Dresel, P.E., and Rose, A.W., 2010, Chemistry and origin of oil and gas well brines in western Pennsylvania: Harrisburg, Pa., Pennsylvania Geological Survey Open-File Oil and Gas Report 10-01.0, fourth series, 47 p., accessed May 7, 2018, at https://www.fractracker.org/a5ej20sjfwe/ wp-content/uploads/2017/08/DreselRose2010.pdf. 


\section{A Comparison of Hydrocarbon-Related Landscape Disturbance Patterns, 2004-2013}

Ebert, D.W., and Wade, T.G., 2004, Analytical tools interface for landscape assessments (ATtILA) user manual (ver. 2004): Las Vegas, Office of Research and Development, U.S. Environmental Protection Agency, EPA/600/R-04/083, accessed October 5, 2011, at https://epa.gov/esd/land-sci/attila/manual/userman.htm.

Fahrig, L., and Merriam, G., 1994, Conservation of fragmented populations: Conservation Biology, v. 8, no. 1, p. 50-59, accessed May 7, 2018, at https://doi.org/10.1046/ j.1523-1739.1994.08010050.x.

Gascon, C., Williamson, G.B., and da Fonseca, G.A.B., 2000, Receding forest edges and vanishing reserves: Science, v. 288, no. 5470, p. 1356-1358, accessed May 7, 2018, at https://doi.org/10.1126/science.288.5470.1356.

Gibbs, J.P., and Shriver, W.G., 2005, Can road mortality limit populations of pool-breeding amphibians?: Wetlands Ecology and Management, v. 13, no. 3, p. 281-289, accessed May 7, 2018, at https://doi.org/10.1007/s11273004-7522-9.

Harper, K.A., MacDonald, S.E., Burton, P.J., Chen, J., Brosofske, K.D., Saunders, S.C., Euskirchen, E.S., Roberts, D., Jaiteh, M.S., and Esseen, P.-A., 2005, Edge influence on forest structure and composition in fragmented landscapes: Conservation Biology, v. 19, no. 3, p. 768-782, accessed May 7, 2018, at https://doi.org/10.1111/j.15231739.2005.00045.x.

Hayden, B.P., 1998, Ecosystem feedbacks on climate at the landscape scale: Philosophical Transactions of the Royal Society of London. Series B, Biological Sciences, v. 353, no. 1365, p. 5-18, accessed May 7, 2018, at https://doi.org/ $10.1098 /$ rstb. 1998.0186 .

Johnson, N., 2010, Pennsylvania energy impacts assessment, Report 1-Marcellus Shale natural gas and wind: [Arlington, Va.], The Nature Conservancy and Audubon Pennsylvania, accessed January 12, 2011, at http:/www.nature.org/wherewework/northamerica/states/ pennsylvania/news/news3511.html.

Kondash, A., and Vengosh, A., 2015, Water footprint of hydraulic fracturing: Environmental Science \& Technology Letters, v. 2, no. 10, p. 276-280, accessed May 7, 2018, at https://doi.org/10.1021/acs.estlett.5b00211.

Laurance, W.F., Nascimento, H.E.M., Laurance, S.G., Andrade, A., Ewers, R.M., Harms, K.E., Luizão, R.C.C., and Ribeiro, J.E., 2007, Habitat fragmentation, variable edge effects, and the landscape-divergence hypothesis: PLoS One, v. 2, no. 10, e1017, accessed May 7, 2018, at https://doi.org/10.1371/journal.pone.0001017.
Lehmkuhl, J.F., and Ruggiero, L.F., 1991, Forest fragmentation in the Pacific Northwest and its potential effects on wildlife, in Ruggiero, L.F., Aubry, K.B., Carey, A.B., and Huff, M.H., Wildlife and vegetation of unmanaged Douglas-fir forests: Portland, Oreg., Forest Service, Pacific Northwest Research Station, U.S. Department of Agriculture General Technical Report PNW-GTR-285, p. 35-46, accessed April 9, 2019, at https://doi.org/10.2737/ PNW-GTR-285.

Marzluff, J.M., and Ewing, K., 2001, Restoration of fragmented landscapes for the conservation of birds - A general framework and specific recommendations for urbanizing landscapes: Restoration Ecology, v. 9, no. 3, p. 280-292, accessed May 7, 2018, at https://doi.org/10.1046/ j.1526-100x.2001.009003280.x.

Matlack, G.R., 1994, Vegetation dynamics of the forest edge-Trends in space and successional time: Journal of Ecology, v. 82, no. 1, p. 113-123, accessed May 7, 2018, at https://doi.org/10.2307/2261391.

McGarigal, K., Cushman, S.A., Neel, M.C., and Ene, E., 2002, FRAGSTATS - Spatial Pattern Analysis Program for Categorical Maps (ver. 3) web page: University of Massachusetts, Amherst, website, accessed May 31, 2011, at http:/www.umass.edu/landeco/research/fragstats/ fragstats.html.

Murcia, C., 1995, Edge effects in fragmented forestsImplications for conservation: Trends in Ecology \& Evolution, v. 10, no. 2, p. 58-62, accessed May 7, 2018, at https://doi.org/10.1016/S0169-5347(00)88977-6.

New York State Department of Environmental Conservation, 2015a, High-volume hydraulic fracturing in NYS: Albany, N.Y., New York State, accessed May 8, 2018, at http://www.dec.ny.gov/energy/75370.html.

New York State Department of Environmental Conservation, 2015b, New York State officially prohibits high-volume hydraulic fracturing: Albany, N.Y., New York State, accessed May 08, 2018, at https://apps.cio.ny.gov/apps/ mediaContact/public/view.cfm?parm=83C73677-C24BB127-1C58E5FC447B4499\&backButton.

New York State Department of Environmental Conservation, 2015c, NYDEC Documentation on data files website: Albany, N.Y., New York State, accessed September 10, 2018, at www.dec.ny.gov/energy/30438.html.

O’Neill, R.V., Hunsaker, C.T., Jones, K.B., Riitters, K.H., Wickham, J.D., Schwartz, P.M., Goodman, I.A., Jackson, B.L., and Baillargeon, W.S., 1997, Monitoring environmental quality at the landscape scale-Using landscape indicators to assess biotic diversity, watershed integrity, and landscape stability: BioScience, v. 47, no. 8, p. 513-519, accessed May 8, 2018, at https://doi.org/10.2307/1313119. 
Riitters, K., Wickham, J., O’Neill, R., Jones, B., and Smith, E., 2000, Global-scale patterns of forest fragmentation: Conservation Ecology, v. 4, no. 2, article 3, accessed July 12, 2012, at https://doi.org/10.5751/ES-00209-040203.

Riitters, K.H., O’Neill, R.V., Hunsaker, C.T., Wickham, J.D., Yankee, D.H., Timmins, S.P., Jones, K.B., and Jackson, B.L., 1995, A factor analysis of landscape pattern and structure metrics: Landscape Ecology, v. 10, no. 1, p. 23-39, accessed May 7, 2018, at https://doi.org/10.1007/ BF00158551.

Roig-Silva, C.M., Milheim, L.E., and Slonecker, E.T., 2019, Natural gas and oil drilling disturbance in the Marcellus Shale region of the New York-Pennsylvania border: U.S. Geological Survey data release, https://doi.org/10.5066/ F7TT4Q67.

Skole, D.L., and Tucker, C.J., 1993, Tropical deforestation and habitat fragmentation in the Amazon; satellite data from 1978 to 1988: Science, v. 260, no. 5116, p. 1905-1910, accessed May 7, 2018, at https://doi.org/10.1126/ science.260.5116.1905.

Slonecker, E.T., and Milheim, L.E., 2015, Landscape disturbance from unconventional and conventional oil and gas development in the Marcellus Shale region of Pennsylvania, USA: Environments, v. 2, no. 2, p. 200-220, accessed May 7, 2018, at https://doi.org/10.3390/environments2020200.

Slonecker, E.T., Milheim, L.E., Roig-Silva, C.M., Malizia, A.R., Marr, D.A., and Fisher, G.B., 2012, Landscape consequences of natural gas extraction in Bradford and Washington Counties, Pennsylvania, 2004-2010: U.S. Geological Survey Open-File Report 2012-1154, 36 p., accessed May 7, 2018, at https://pubs.usgs.gov/of/ 2012/1154/.

Stevens, S.H., and Kuuskraa, V.A., 2009, Special report-GAS SHALE_-1-Seven plays dominate North America: Oil \& Gas Journal, Special Report_-Trends in Unconventional Gas, v. 107, no. 36, p. 39-49, accessed April 9, 2012, at http://www.ogj.com/articles/print/volume107/issue-36/Drilling__Production/special-report-gasshale-1-seven-plays-dominate-north-america-activity.html.

Turner, M.G., 2005, Landscape ecology_-What is the state of the science?: Annual Review of Ecology Evolution and Systematics, v. 36, no. 1, p. 319-344, accessed May 7, 2018, at https://doi.org/10.1146/ annurev.ecolsys.36.102003.152614.
Turner, M.G., Gardner, R.H., and O’Neill, R.V., 2001, Landscape ecology in theory and practice-Pattern and process: New York, Springer, 401 p., 1 CD-ROM.

U.S. Geological Survey, 2002, Energy Resources Program website: Appalachian Basin province code 5067, accessed May 10, 2018, at https://energy.usgs.gov/ OilGas/AssessmentsData/NationalOilGasAssessment/ USBasinSummaries.aspx?theTab= dataTab\&provcode $=5067$.

U.S. Geological Survey, 2011, The National Map web page: U.S. Geological Survey website, accessed May 8, 2018, at https://viewer.nationalmap.gov/advanced-viewer/.

White, P.S., and Pickett, S.T.A., 1985, Natural disturbance and patch dynamics - An introduction, in Pickett, S.T.A., and White, P.S., eds., The ecology of natural disturbance and patch dynamics: Orlando, Fla., Academic Press, p. 3-12. [Also available at https:/www.sciencedirect.com/science/ book/9780125545204.].

Wickham, J.D., O’Neill, R.V., Riitters, K.H., Wade, T.G., and Jones, K.B., 1997, Sensitivity of selected landscape pattern metrics to land-cover misclassification and differences in land-cover composition: Photogrammetric Engineering and Remote Sensing, v. 63, no. 4, p. 397-402.

Wickham, J.D., and Riitters, K.H., 1995, Sensitivity of landscape metrics to pixel size: International Journal of Remote Sensing, v. 16, no. 18, p. 3585-3594, accessed May 7, 2018, at https://doi.org/10.1080/01431169508954647.

Wickham, J.D., Riitters, K.H., Wade, T.G., Coan, M., and Homer, C., 2007, The effect of Appalachian mountaintop mining on interior forest: Landscape Ecology, v. 22, no. 2, p. 179-187, accessed May 8, 2018, at https://doi.org/ 10.1007/s10980-006-9040-z.

Wickham, J.D., Wade, T.G., and Riitters, K.H., 2008, Detecting temporal change in watershed nutrient yields: Environmental Management, v. 42, no. 2, p. 223-231, accessed May 7, 2018, at https://doi.org/10.1007/s00267008-9120-8.

With, K.A., and Pavuk, D.M., 2011, Habitat area trumps fragmentation effects on arthropods in an experimental landscape system: Landscape Ecology, v. 26, no. 7, p. 1035-1048, accessed May 7, 2018, at https://doi.org/ 10.1007/s10980-011-9627-x. 


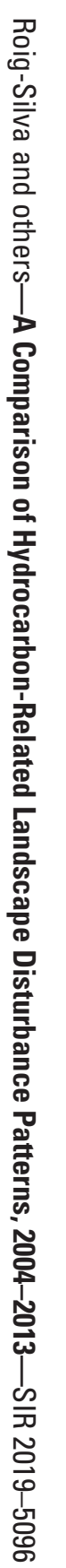

